\title{
Anders Boserup Modsætninger og kampe i Nordirland
}

Det følgende essay har to formål. Det første er praktisk-politisk: et angreb på den strategiske linie det katolske venstre i Nordirland har anlagt, og som også venstrefløjen i England og andre steder har givet sin opbakning. Essayets umiddelbare indhold, analysen af konflikten i Nordirland og oversættelsen af denne analyse til den dertil svarende politiske strategi, ligesåvel som dets sine steder polemiske form er bestemt af dette formål. Ved fordanskningen har jeg suppleret på teksten i ret betydelig grad, men uden at søge at ændre dens oprindelige karakter. ${ }^{1}$

Dette til trods for at det andet formål, det teoretisk-metodiske, nok har større interesse for en dansk læserkreds. Dette formål er sådan set i første række rent privat: et forsøg på at udforske sammenhængen mellem den teoretiske analyse af de dominerende modsætninger i en samfundsformation og den strategiske analyse af denne samfundsformations dominerende konflikter. Teoretisk set ligger vanskeligheden $i$ at karakterisere relationen mellem en modsætnings aspekter på den ene side og en strategis tyngdepunkter på den anden; ${ }^{2}$ metodisk ligger den i kompleksiteten af den sammenhæng der er mellem en modsætning og dens fremtrædelsesformer som konflikt i en given samfundsformation. Det er især denne sidste sammenhæng der her søges studeret »in vivo«.

Det irsk-katolske venstres grundliggende teori går ud på at konflikten i Nordirland udspringer af en hovedmodsætning mellem imperialistisk dominans og national frigørelse. Jeg søger nedenfor at vise, at denne teori er uforenelig med

1. Essayet er først udgivet på engelsk i Independent Labour Party's politiske skriftserie under titlen „Who is the Principal Enemy?« (Square One Pamphlets, nr. 5, 1972), og er siden udkommet i The Socialist Register 1972 (Merlin Press, London, 1972) under samme titel som her.

2. Det er det problem Clausewitz anskuer som forholdet mellem krig og politik. Om dette og strategiens tyngdepunktsbegreb, se min og Andrew Mack's »Ikke-vold som nationalforsvar«, kapitel X (Spektrums Aktuelle, København 1971). 
kendsgerningerne, fører til en strategisk blindgyde og er med til at låse den irske arbejderklasse fast i dens sekteriske ideologier. Den virkelige hovedmodsætning bag de seneste års kampe i Nordirland er en ganske anden: det er modsætningen mellem på den ene side en traditionel, »klientilistisk « form for kapitalistisk samfundsformation, hvis institutionelle udtryk bl.a. udgøres af Orangeordenen og de bredere lag i det Unionistiske parti, og på den anden side den »normale«, nutidige form for kapitalistisk samfundsformation, der er forbundet med de store internationale selskaber og begreberne monopolkapitalisme og velfærdsstat. Analysen af disse formationer antyder den centrale betydning for overgangen mellem dem af henholdsvis kobling og autonomi mellem det økonomiske niveau på den ene side og de ideologiske og politiske niveauer på den anden. Det er her (konkret f.eks. i reform- og velfærdspolitikken) at strategiens tyngdepunkt må søges.

Essayet er for størstepartens vedkommende skrevet i slutningen af 1971, endnu før den tilspidsning af kampen mellem IRA (den irske republikanske hær) og den engelske hær, der fulgte med interneringen af katolske politiske og IRA ledere. Meget er sket siden da: Londons overtagelse af regeringsmagten i foråret 1972, fremvæksten af den protestantiske private forsvarsarmé, Ulster Defence Association, som en afgørende politisk og militær faktor, og, efter myndighedernes effektive udrensning i det "provisoriske« IRA's ledelse i juli 1972, overgangen til en mere blind og tilfældig, mindre politisk, men ikke mindre morderisk øje-for-øje-og-tand-for-tand snigmordskampagne. Disse ustandselige omvæltninger i den politiske og militære situation, der får problemerne, prioriteringerne og kampene fra for blot et år siden til at synes fjerne og irrelevante idag, er der kun i ringe grad taget hensyn til under omskrivningen til den danske udgave.

Jeg tror dog ikke, at en analyse af irske socialisters strategiske alternativer af den grund forældes på så kort tid. Kampenes mangfoldighed og deres ustandselige vekslen lige siden 1968 udgør netop beviset - om noget havde været krævet - på at deres betydning kun er episodisk. De er kun de underliggende modsætningers øjeblikkelige fremtrædelsesformer. Strategiens opave er at bestemme disse modsætninger og med dem de punkter, hvor politisk handling mest effektivt kan sættes ind. Heri ligger hele forskellen mellem politisk improvisation og en strategi, der bygger på teori. Og i dette perspektiv er de vekslende kampe på den politiske arena ikke direkte bestemmende for strategien. Deres betydning ligger andetsteds: for så vidt angår den politiske praksis afgrænser de det felt inden for hvilket strategien må omsættes konkret, og forsåvidt angår det teoretiske område udgør de den virkelighed overfor hvilken modsætningernes værdi som tolkningsinstrument skal prøves.

Selv om det fortrinsvis er ved det teoretisk-metodiske sigte, at dette essay kan have interesse for den danske læser, skal det dog fremhæves, at helt udenfor 
kampene i Nordirland står han ikke. Strategiske overvejelser tilkommer ikke kun irerne, for velmenende mennesker andre steder har haft en betydelig indflydelse på de hidtidige begivenheder i Nordirland og har et tilsvarende ansvar og tilsvarende muligheder hvad den kommende udvikling angår. Borgerretsbevægelsens oprindelige gennembrud i 1968-69 ville have været utænkeligt, og den protestantiske reaktion på det unødvendig, uden den bølge af sympati for katolikkernes sag, der rejste sig i udlandet. På tilsvarende vis er den engelske hærs egentlige opgave idag at skabe det skin af retfærdighed og orden, som vil virke overbevisende på folk udenfor Irland. Hvordan og hvorvidt den fremturer over for henholdsvis katolikker og protestanter afhænger lige så meget af reaktionerne i England og i den øvrige verden som af kampenes forløb i Nordirland selv. Sidst men ikke mindst er udsigterne for IRA’s forsøg på at tvinge englænderne til at trække sig tilbage ved at øge omkostningerne ved »besættelsen « af Nordirland helt afhængige af, hvilken støtte dets krav om en genforening kan vinde i England og andre steder, hvor rimeligt og naturligt, men også hvor uomgængeligt dette krav forekommer udenfor Irland. Det er derfor afgørende, at socialister også uden for de britiske øer skal forstå, at når de slutter op bag den opfordring til solidaritet i kampen mod den britiske imperialisme, som man også med mellemrum kan læse på husmurene i København, så forråder de i virkeligheden socialismens idealer og støtter en politik for national undertrykkelse af det protestantiske mindretal i Irland, der er den internationale arbejdersolidaritets modpol.

\section{Delingen af Irland}

For at forstå fremvæksten af to forskellige nationalismer i Irland i anden halvdel af det nittende århundrede og oprettelsen af to forskellige statsdannelser i begyndelsen af det tyvende er det nødvendigt først at fremdrage visse aspekter af den økonomiske og politiske udvikling, der førte frem til delingen. Dette giver også den nødvendige baggrund for at forstå, hvordan koalitionen omkring Orangeordenen voksede frem i Ulster, og hvorfor man idag finder en udvikling i retning af en genforening af øen, i hvert fald i økonomisk henseende.

I det attende århundrede var den økonomiske situation den omvendte af, hvad den er idag. I den sydlige del af øen, det der nu er den Irske Republik, fandtes en blandet økonomi med forholdsvis store industrier og landbrug, medens den nordlige del, Ulster, næsten udelukkende var landbrugsland. Mod enden af århundredet var de sydlige industrier begyndt at gå tilbage: anvendelsen af kul i industrien - maskinvæve, jernsmeltning med kul og anvendelsen af dampmaskiner ved højovnene - gav de irske industrier et handicap i forhold til deres engelske konkurrenter. Hertil kom, at indførelsen af arbejdsbesparende 
metoder i industrien var vanskeliggjort af det forældede lavssystem $\mathrm{i}$ attenhundredetallets Irland og af svagheden hos den besiddende klasse, der byggede på jordejendom og handel snarere end industri.

Landbruget i Sydirland var så fattigt, at det ikke udgjorde et tilstrækkeligt grundlag for en hjemmemarkedsindustri. Dette beroede på jordbesiddelsessystemet i syden, det såkaldte »tenancy-at-whim « system - dvs. forpagtning underkastet ejerens luner - med meget korte lejekontrakter, sjældent på mere end et år. Under disse forhold havde fæsteren ingen interesse i (eller overskud til) at forbedre jorden og investere i landbruget, og ejeren tilskyndedes til at pine alt overskud ud som jordrente og holde fæsterne på, og undertiden under, hvad der i bogstaveligste forstand var et eksistensminimum.

I modsætning hertil blev Ulster udstykket meget senere, og et andet fæstesystem med mangeårige fæstekontrakter, kendt som »Ulster sædvanen «, udviklede sig der. I virkeligheden blev grevskaberne Antrim og Down langs den nordøstlige kyst, nu de mest protestantiske og højest udvikede dele af Ulster, slet ikke udstykket af den engelske regering, men af skotske imigranter. Betinget af »Ulster sædvanen « blev jordforbedringer tillokende for fæsteren, et vist overskud kunne fremkomme, og hjemmeindustrier begyndte at vokse frem, særligt lærredsfremstilling. Således fremmedes en lokal kapitalakkumulation og væksten af et hjemmemarked for industri- og håndværksprodukter. Særligt afgørende var det, at Ulsters lærredsindustri var et sideerhverv byggende på sæsonledighed i landbruget og ikke som i syden på et byproletariat af helårsbeskæftigede lønarbejdere. Ulsters industri var derfor i stand til at overleve på trods af den intense engelske konkurrence i begyndelsen af det nittende århundrede, hvor industrien i det øvrige Irland brød sammen.

Ulster var derfor ene om at kunne drage fuld nytte af lærredindustriens forbedrede vilkår efter 1820. Industrier kunne opstå både på forsynings- og aftagersiden af lærredsfremstillingen: skjortefremstilling i Londonderry og en begyndende maskinindustri til at forsyne tekstilfabrikkerne. I modsætning til den sårbare og overfladiske industrialisering i Sydirland i det attende århundrede kom det nittende århundredes industrialisering af Ulster som en »normal og sund udvikling.$^{3}$ Mod slutningen af århundredet bestod Irland igen af to adskilte økonomier, men denne gang geografisk adskilt: I syden var der en omfattende bondebefolkning, der levede på et eksistensminimum, og som kun langsomt var ved at komme sig efter den store hungersnød, og et tyndt lag af godsejere og handelsbourgeoisi. Industrien var lidet udviklet. I Ulster derimod var det industrielle bourgeoisi den økonomisk dominerende klasse, og denne klasse var tilmed ved at fravriste godsejerklassen den politiske ledelse. Belfast var et hastigt voksende industri- og handelscenter med al 
den dynamik, selvtillid og ubeskrivelig folkelig elendighed, som karakteriserede den tidlige kapitalisme. Kort sagt: syden var en slags neo-kolonialistisk samfund, medens Ulster var hverken mere eller mindre end en integreret del af den britiske økonomi.

Dette var de hårde realiteter bag delingen af Irland. ${ }^{4}$ De orangefarvede skærf og de grønne bannere var blot deres politiske fremtrædelsesformer. Disse realiteter gjorde Nationalisternes drøm om et forenet og uafhængigt Irland utopisk. Ikke alene havde øens to halvdele forskellige økonomiske forhold: De to økonomier var hverken komplementære eller forenelige. De nordlige industrier var fuldstændigt afhængige af forbindelsen til det britiske marked, og hertil var markedet i syden ikke noget brugbart alternativ. Norden var heller ikke et muligt marked for sydens landbrugsprodukter: Begge områder eksporterede landbrugsvarer. Men først og fremmest var de herskende klassers interesser i henholdsvis nord og syd helt uforenelige. Industrierne i den nordlige del kunne kun overleve ved en frihandelspolitik over for Storbritannien, men en sådan politik kunne det ikke forventes, at en samlet irsk republik ville føre. For udviklingen af industrier i syden ville være umulig, med mindre den kunne foregå bag en beskyttende toldmur.

Spændinger og konflikter mellem forskellige trossamfund har været et tilbagevendende tema i Irlands historie gennem århundreder. Nogle har heraf søgt at slutte, at religiøse modsætningsforhold i Irland blot er et levn fra kolonitiden, resterne af holdninger, der stammer tilbage fra den engelsk-protestantiske erobring af det katolske Irland og konfiskeringen og udstykningen af jorden til fordel for engelske og skotske indvandrere i det syttende århundrede, levn, som siden skulle være gået i arv gennem Ulsters tvedelte institutioner: skoler, loger og hemmelige selskaber osv. Andre har søgt at forklare dette tilbagevendende træk ved materielle faktorers vedvarenhed, først og fremmest den britiske imperialisme og dens interesse i at opretholde og uddybe skellene i den irske arbejderklasse. I modsætning til begge disse tolkninger er et af hovedsynspunkterne i denne artikel, at selv hvor stridende, kulturelt eller racemæssigt afgrænsede grupper synes at have ligget i permanent konflikt gennem lange perioder, som tilfældet har været i Irland, er brydningerne i forskellige epoker ikke desto mindre udtryk for modsætninger, der er specifikke for hver epoke. Billedligt talt kunne man ligne situationen med en krystal: ligegyldigt hvilke kræfter krystallen udsættes for, sprænges den altid på samme måde. Men fordi virkningerne stedse er de samme, følger ikke at påvirkningerne må have været ens. Indtrykket af århundredelang kontinuitet i konflikten i Irland er ligesåmeget en illusion som indtrykket af ustandselig diskontinuitet i de sidste fem år. 
Dette fremgår tydeligt, hvis man ser tilbage gennem historien. Skillelinien mellem modstående grupper har flyttet sig adskillige gange. De bigotte og sekteriske holdninger, som findes i Ulster idag, kan ikke føres længere tilbage end til 1830'erne. Og de modsætninger, som lå bag kriserne i 1920 og i 1970 er vidt forskellige, selv om kriserne, overfladisk betragtet, kan forekomme meget analoge.

I slutningen af det attende århundrede var næsten hele Belfasts befolkning presbyteriansk. Byen havde ingen industri, men var et driftigt handelscenter med en stærk liberal tradition. Revolutionerne i Amerika og i Frankrig blev fulgt med sprudlende begejstring, og Bastillens fald blev fejret i gaderne. Presbyterianerne i Belfast var blandt lederne af bevægelsen »United Irishmen«, et hemmeligt selskab rettet mod det anglikanske herredømme og med et program, som var ret lig de franske revolutionæres. Denne presbyteriansk ledede opstand søgte at støtte sig til en katolsk bonderejsning, således at presbyterianerne i 1798, i absolut modsætning til deres nuværende ry, på een gang var heftigt liberale og den katolske frigørelses hovedfortalere.

På landet var situationen en anden. For de protestantiske fæstebønder udgjorde katolikkerne en trussel om bortdrivelse fra landet, da de af bitter nød ofte var villige til at give afkald på fordelene ved »Ulster sædvanen« og tage korte lejemål. Et stort antal hemmelige selskaber opstod på denne tid på begge sider for at beskytte fæsternes interesser, om nødvendigt ved straffeekspeditioner og terrorhandlinger. Orangeordenen, idag en af de vigtigste institutioner i Nordirland, blev grundlagt i 1795 og var oprindeligt et sådant anglikansk (dvs. højkirkeligt) broderskab. Den blev benyttet med held af jordejerne i 1798 til at knuse det oprør, United Irishmen havde sat igang.

Som anført var kampene omkring United Irishmen bevægelsen i deres væsen et opgør mellem klasser, men det er nyttigt at gøre sig klart, hvordan sådanne opgør, dengang som nu, i væsentlig grad udspiller sig på et tilsyneladende religiøst grundlag. Den kamp, hvori United Irishmen bevægelsen var et moment, var en kamp om den politiske magt mellem på den ene side godsejere, landadel og store handelsfolk, det magthavende oligarki, samlet i den anglikanske kirke, og på den anden side presbyterianerne, dvs. småborgerskabet og håndværkerstanden, delvis i alliance med såvel protestantiske (presbyterianske) som katolske bønder. Ideologisk fik denne magtkamp derfor form af en kamp for demokratisk lighed. Der var et vidtgående sammenfald mellem klasser og religiøst tilhørsforhold, der ikke blot skyldtes, at de forskellige klasser i Ulster var efterkommere efter forskellige grupper af indvandrere, der havde haft hvert sit (klassebestemte) kirkelige tilhørsforhold i England, det skyldtes også at kirkesamfundene dengang var de vigtigste politiske organisationer og derfor i deres indbyrdes modsætningsforhold, politisk såvel som ideologisk, afspejlede klassemodsætningerne mellem deres medlemmer. Tidens dominerende religiøse spørgsmål måtte enhver tros- 
retning tage stilling til, men i virkeligheden var disse spørgsmål blot de politiske stridsemners religiøse iklædning. Hovedforskellen mellem den anglikanske kirke, der var langt den vigtigste episkopale kirke på de britiske øer, og de presbyterianske trossamfund lå, som også betegnelserne antyder, i kirkernes organisation: et bispesystem i første tilfælde, hvor udnævnelser foregik hierarkisk nedefter, og hvor det kirkelige hierarki i sidste instans var underkastet statsmagten: kirken som de herskende klassers ideologisk-politiske instrument over for masserne; et menighedssystem (presbyter) i det andet tilfælde, hvor udnævnelser skete nedefra opefter, hvor menighedsrådene var politisk autonome og demokratisk opbygget, og hvor præstegerningen var de-sakraliseret. Men ikke blot kampen om kirkens politiske autonomi og menighedens demokratiske organisation, også synodernes kampskrifter og teologernes spidsfindige teser og udlægninger var blot de religiøse former klassekampen antog i den epoke. Stridens sande indhold var kampen for den demokratiske styreform, ikke alene i kirken, men i staten. Prædestinationen var det store teologiske stridsspørgsmål mellem anglikanere og presbyterianere. Også her repræsenterede anglikanerne, for hvem Guds nåde ikke indvirkede ens på alle, et aristokratisk syn, medens presbyterianernes tese, at den enkeltes frelse eller fordømmelse er forudbestemt og upåvirket af hans gerninger og af Guds tilsyneladende gunst i denne verden, i den tids perspektiv svarede til kravet om alle menighedens medlemmers demokratiske lighed.

I de første årtier af det nittende århundrede fortsatte kampen på en mere tydelig politisk form som en langtrukken strid mellem de liberale og konservative fraktioner om kontrollen med den presbyterianske kirke, dvs. med de protestantiske masser. I sidste ende var det den konservative fløj, der vandt overhånd. Et stort antal liberale ledere var blevet henrettet efter opstanden $\mathrm{i}$ 1798. Industrierne i Belfast var i hurtig vækst, og det samme gjaldt det katolske proletariat. Mellem 1800 og 1830 var katolikkernes andel af befolkningen i Belfast vokset fra 10 pct. til 33 pct. De katolske arbejdere var ofte villige til at gå for en sulteløn, og dermed var der også i byerne skabt grundlag for et modsætningsforhold mellem katolikker og protestanter. Ved at ophæve lovgivning der diskriminerede mod presbyterianere, og ved bevidst at fremme anti-katolsk bigotteri blandt de fattige i byerne, lykkedes det den konservative fløj at overtage ledelsen af den presbyterianske kirke. I 1829 brød den liberale fløj ud for at danne en uafhængig presbyteriansk kirke, derved efterladende hovedparten af presbyterianerne i torypartiets og godsejernes indflydelsessfære.

Liberalismen forblev stærk blandt borgerskabet $\mathrm{i}$ byerne, men på grund af denne splittelse mistede den meget af sin hidtidige indflydelse på arbejdere, håndværkere, småhandlende og den brede befolkning i øvrigt. For at sikre sig at en liga, rettet mod godsejerne, som United Irishmen havde været det, aldrig skulle kunne opstå igen, blev Orangeordenen genoplivet og åbnet for presbyteriansk medlem- 
skab (officielt i 1834). Orangemarcherne og tilbagevendende gadeoptøjer - af hvilke et betydeligt antal var fremprovokeret med fuldt overlæg af det presbyterianske præsteskab - tjente til at styrke sekterismen og terrorisere katolikkerne. De første større optøjer synes at have været dem, der fandt sted i 1835, og herefter og indtil udgangen af århundredet blev de genoplivet med tre til ti års mellemrum. ${ }^{5}$

Omkring 1886, på det tidspunkt hvor det første lovforslag om irsk selvstyre (Home Rule) blev fremsat i det britiske parlament, var irsk politik domineret af tre partier: Torypartiet, det konservative parti, der i Irland, i modsætning til England, endnu fortrinsvis var godsejernes parti; Whigpartiet, det liberale parti, hvis grundlag var det industrielle borgerskab, og som var på vej til at genvinde sin styrke i Ulster; og Nationalistpartiet, der var en noget forvirret samling af middelklasseborgerskab, mindre ejendomsbesiddere og den af det katolske præsteskab ledede bondebefolkning. Lovforslaget om irsk selvstyre blev fremsat af en liberal mindretalsregering i London, der støttede sig parlamentarisk til de irske nationalister. Dets fremsættelse førte til et næsten øjeblikkeligt og fuldstændigt omsving blandt de irske liberale og førte til dannelsen af en Unionistisk koalition, der samlede modstandere af irsk selvstyre, jordaristokratiet, det industrielle borgerskab og Orangelogerne i en kompakt blok. Omsvinget betød selvfølgelig ikke en ændring i disse gruppers politik, kun en ændring i prioriteringen, en omorganisering, hvorved uoverensstemmelserne mellem industrialister og jordejere blev udskudt til mindre kriseagtige tider. Orangeordenen, med »sit system af lokale loger, forbundet til en storloge i hvert grevskab, udgjorde en færdigtømret ramme for en effektiv organisation. Umiddelbart efter fremsættelsen af Gladstones første lovforslag om selvstyre i 1886 fik Ordenen en enorm styrketilførsel. I stort tal sluttede landadel og godsejere, præster fra alle protestantiske sekter, erhvervsfolk og akademikere, bønder og de bedrestillede håndværkere i Belfast og andre store byer sig til logerne, hvis ledelse kom på dygtige hænder; Ordenen blev derved hurtigt og fuldstændigt ændret, og i stedet for at blive anset for et noget vanrygtet og udrangeret levn blev det en yderst respektabel og tilligemed overordentlig mægtig politisk organisation. $\aleph^{6}$ Ved hjælp af det anti-katolske bigotteri samledes hele det protestantiske samfund i den nordlige del af Irland omkring Unionismen, hvilket skabte et massegrundlag, som man i påkommende tilfælde ville kunne regne med i en væbnet konflikt. Og netop af samme grund udelukkede den Unionistiske alliances orange kolorering enhver mulighed for kompromis mellem erhvervsinteresserne i Nord og Nationalisterne, for eksempel i form af landreformer eller af økonomiske indrømmelser til middelklassen, fordi Unionismen på denne måde skiftede fokus fra de økonomiske og sociale interesser, der egentlig lå til grund, til religiøse eller, mere nøjagtigt, til nationale spørgsmål.

5. Se Andrew Boyd: Holy War in Belfast, Dublin 1969.

6. Ronald McNeil: Ulster's Stand for Union, London 1922. 
Efterhånden som krisen tog til i årene op til første verdenskrig, var den vigtigste faktor, der holdt den Unionistiske blok sammen, et virkeligt sammenfald af korttidsinteresser. Men sammenholdet lettedes også af Nationalisternes manglende evne eller uvillighed til at anerkende den sande karakter af Unionisternes modstand mod selvstyre. Ulster var uden tvivl den mest fremskredne del af Irland, og landsdelens afvisning af at blive tvunget ind i en stat, som den ikke havde noget nationalt tilhørsforhold til, ikke havde nogen økonomiske fællesinteresser med, og som så ud til at blive politisk reaktionær og domineret af den katolske kirke, blev aldrig ordentligt forstået af Nationalisterne. I stedet syntes de at gå ud fra, at Unionisterne ikke bestod af meget andet end et »lumpenbourgeoisi « og et lumpenproletariat, som blev vildført af godsejerne. Ulsters modstand mod selvstyre blev derfor anset for et problem, der måtte tilskrives hysteri og sentimentalisme snarere end solide og velforståede interesser, et problem der derfor med tiden ville løse sig selv, og som i den aktuelle situation om nødvendigt kunne klares med tvang. I virkeligheden stod den mest fremskredne del af den irske arbejderklasse, de protestantiske arbejdere i Belfast, fuldt og fast bag Unionismen - og ikke uden god grund: Selvstyre udgjorde en direkte trussel mod deres beskæftigelse og deres indkomst, som det gjorde for de fleste andre mennesker i den industrialiserede nordøstlige del af Irland.

Blandt nutidens katolske nationalister kan man finde den samme tilbøjelighed til at henføre den protestantiske arbejder- og middelklasses modstand mod Irlands genforening til imperialismens og de herskende klassers sammensværgelser, propaganda og manipulation. I halvfjerdserne, lige så vel som i tyverne, betyder det en grov, og politisk set katastrofal undervurdering af de kræfter som nationalisterne står overfor.

Godsejernes politiske dominans blandt Unionisterne var helt ude af takt med deres reelle styrke - i det mindste i Ulster. Før delingen i 1920 var deres magt blevet brudt ved landreformerne omkring århundredeskiftet. Skønt det er omsonst at spekulere over historiske »hvis'er« er det ikke desto mindre værd at bemærke, at en lang række træk ved Unionismen i Ulster, dens orange farvning, dens forbindelser til det konservative parti i England og dens politiske arkaiske karakter og oligarkiske struktur, i vidt omfang må tilskrives tilfældigheder ved tidspunktet for dens tilblivelse.

Som forholdene var, overlod Unionistblokkens industrifyrster imidlertid det politiske initiativ til godsejerklassen. ${ }^{7}$ Unionistblokken opstod som en alliance med en liberal økonomisk politik, hvis styrke i sidste ende hidrørte fra det industrielle borgerskab, men hvis ideologiske perspektiv var domineret af godsejer- 
klassen på den ene side og på den anden side af arbejder- og middelklassens af Orangeordenen inspirerede sekterisme.

\section{Den Orange Samfundsorden}

Efter delingen opstod et ganske særegent samfundssystem i Nordirland. Det hvilede på to hovedelementer: Det ene var den vedvarende trussel mod staten, som hidrørte fra den militante republikanisme syd for grænsen og, nord for grænsen, fra katolikkernes manglende loyalitet. Det andet var fortsættelsen af den »Orange« koalition med dens sekteriske politik. Denne samfundsformation er i disse år ved at blive nedbrudt, men for at forstå de modsætninger, der ligger til grund for de sidste års kampe i Irland, er det nødvendigt at give en kort fremstilling af det samfundssystem, der har domineret i Ulster i næsten et halvt århundrede. ${ }^{8}$

Som andre politiske systemer hviler Orangevældet på en organiseret solidaritet mellem de forskellige eliter. Men systemet er originalt derved, at dets styrke er at finde på det lokale niveau, i småbysamfundene, snarere end på provinsniveau - altså det niveau der omfatter Nordirland i sin helhed. Denne solidaritet hviler på et nært samarbejde mellem det lokale styre, Orangeordenen, de protestantiske kirker, Unionistpartiets lokale organisationer, ledelsen af lokale virksomheder, udøverne af de liberale erhverv osv.

Orangeordenen er denne konservative alliances hjørnesten. Det er et hemmeligt selskab af frimureragtig karakter, hvis medlemmer overvejende kommer fra arbejderklassen, bondestanden og den lavere middelklasse. Dens udbredelse er ikke kendt, men medlemstallet synes at variere fra een protestantisk mand ud af tre, måske noget mere, i og omkring Belfast, til op imod 90-95 pct. af alle voksne protestantiske mænd i katolskdominerede landdistrikter. Der findes også særlige loger for de liberale erhverv, teknikere og funktionærer, men under normale forhold er middelklassen tilbøjelig til at se ned på Ordenen og dens hemmelige ritualer og antikverede symbolik. Politiet har sin egen loge, »Cromwell's Ironsides«, og Ordenen er forbundet med en række lignende, men meget mindre organisationer, som "Apprentice Boys of Derry« og de mere ekstreme »Royal Black Preceptory« og »Royal Purple Arch«.

Selv om Ordenen først og fremmest er en anti-katolsk kamporganisation, kan dens udbredelse og styrke kun forstås på baggrund af de væsentlige funktioner den opfylder, også inden for den protestantiske gruppe. Man må huske på, at protestanterne spænder over et bredere socialt spektrum end katolikkerne og er langt mere splittet religiøst set. På begge disse områder udgør Orangeordenen et væsentligt

8. Af pladshensyn gives her kun en skitse. Pålidelig dokumentation for diskriminering findes i publikationerne fra Campaign for Social Justice in Northern Ireland, i Orange and Green, udgivet i 1969 af Northern Friends' Peace Board og mange andre steder. Se også min Revolution och Motrevolution i Nordirland, Världspolitikens Dagsfrågor, nr. 12, Stockholm 1970. 
samlingspunkt. På grund af dens egalitære ideologi er det trods alt det sted, hvor folk fra de lavere samfundslag føler de kan tale mere åbent til de mere indflydelsesrige protestanter, hvor de kan lade deres røst høre, få afløb for utilfredshed og opnå forbindelser, stillinger, privilegier osv. Det er utvivlsomt heri man må søge grunden til ordenens tiltrækningskraft for de lavere klasser og til den langt mere negative holdning der er til den i de socialt bedre stillede samfundslag.

Ordenen er også et bindeled mellem de forskellige protestantiske trosretninger, der i Nordirland ofte har et mindre harmonisk forhold til hinanden, end man gerne forestiller sig. Trossamfundene har noget forskellig klassesammensætning, og mistillid og gensidig nedvurdering mellem klasserne afspejler sig derfor i forholdet mellem de forskellige menigheder. For de bedrestillede medlemmer af de episkopale kirker, dvs. for den højere middelklasse, er presbyterianeren en dydsiret, hellig rad, medens presbyterianeren kan pege på Church of Ireland medlemmer (f.eks.), både blandt dem der står over, og dem der står under ham socialt set, hvis livsform er en sådan, som ingen »anstændig « presbyterianer med respekt for sig selv ville gå med til. De ugentlige møder i Logen bringer de forskellige trosretninger sammen, giver dem en fællesskabsfølelse, og Ordenen fungerer egentlig som en fælles, trosretningsfri kirke for alle protestantiske mænd. Det gør den, fordi den hyppigt er et alternativ til den regelmæssige kirkegang, der, i hvert fald i småsamfundene, ellers ikke ville være til at komme udenom. Mændene kan overlade gudstjenesten til kvinder og børn og alligevel vise deres solidaritet over for det protestantiske samfund ved at deltage regelmæssigt i Logens møder. De kan dér træffe vennerne, ofte over et krus øl, samtidig med at de gør deres samfundspligt som gode protestanter. Logen er altså ikke blot en kamporganisation. Den er også en trosfri kirke, en klub, en interesseorganisation og et forbindelsesled til de indflydelsesrige protestanter.

Både formelt og uformelt er Ordenen knyttet på en række forskellige måder til Unionistpartiet. Dette er et "paraplyparti«, som omfatter protestanter af alle klasser. Det har et sikkert flertal i så godt som alle lokalråd, sikkert fordi stemmeflytning ved valgene næsten ikke forekommer. Stemmemønsteret er så rigidt, og valgresultaterne så forudsigelige, at det er forekommet, at så meget som 70 pct. af samtlige mandater, der var på valg, blev besat uden modkandidater.

I Nordirland er det ikke valgene, men fødselstallene, der afgør regeringens og lokalrådenes farve. Men det betyder ikke, at valgene blot er et formålsløst ritual, et ideologisk slør. Et valg er i høj grad en politisk kamp og en politisk afgørelse, men af en helt anden karakter end dem, vi er vant til. Det er ikke et valg mellem orange og grønne partier, for stemmeflytning forekommer som sagt ikke. Faren er ikke, at »modparten « gør indhug i ens stemmer ved at appellere mere effektivt til det politiske centrum, for et sådant eksisterer ikke. Faren er, at yderfløjen på ens egen side river sig løs. Og med et system med enkelt- 
mandskredse kan selv et lille splittelsesparti på den ultra-orange fløj føre til, at katolikkerne vinder mandatet. I modsætning til f.eks. Danmark, hvor et valg - i hvert fald for de store partiers vedkommende - er en ret så farveløs bejlen til marginalvælgeren, til den der står i midten af det politiske spektrum og ikke har nogen særligt markerede politiske synspunkter, er et valg i Nordirland en bejlen til yderfløjene, til det flammende orange og til det giftigt grønne, for det er der, den virkelige risiko findes. I stedet for en indbygget dæmper, som tilfældet er her i landet og de fleste andre steder, er der i det nordirske valgsystem, med kombinationen af et fastlåst stemmemønster og enkeltmandskredse, en indbygget forstærker for politiske forskelle - et forhold der ikke bør overses, når man undres over voldsomheden i den politiske retorik i Nordirland.

Af en lang række grunde er det af afgørende betydning for protestanterne at have et sikkert flertal i alle de lokale råd. Een grund er, at by- og landrådene bygger og ejer en trediedel af alle huse og har stor indflydelse på placeringen af de resterende to trediedele. De er derfor i stand til at påvirke befolkningsudviklingen, herunder den religiøse sammensætning, i de forskellige valgkredse. De kan opmuntre protestanter til at bosætte sig og katolikker til at udvandre.

Tilsvarende mål kan nås ved diskriminering i ansættelsespolitikken. De lokale råd tager vare om sundhedsvæsen, uddannelsessystemet og velfærdstjenesten og ansætter direkte eller indirekte enhver fra hospitalskirurgen til skolebuschaufføren. Diskriminering er en dagligdags foreteelse ved tildelingen af sådanne stillinger og af alle andre stillinger, som er forbundet med den lokale administration. Også vejbyggeri henhører under lokalrådene. Vejarbejde beskæftiger et betragteligt antal arbejdere og er således et smidigt instrument til at regulere arbejdsløsheden med. Det anses for fuldkommen normalt at sådanne jobs går til folk, der er loyale mod styret. Beskæftigelse ved offentlige arbejder tjener således til at styrke loyaliteten hos de fattige, og da det for en stor del består af deltidsarbejde, er det af særlig betydning for småbønderne, som ofte kun kan få det til at løbe rundt, hvis de har et ekstrajob i vintermånederne. Indrulering i det halvt militære, halvt politiagtige officielle frivilligkorps, »B-specials«, havde en lignende funktion.

Det er en misforståelse at tro, at B-specialstyrken blot bestod af mænd, der aldrig var nået ud over spejderalderen, eller af sadister, hvis fornøjelse det var at chikanere eller terrorisere katolikkerne. Mange protestanter, særligt i landdistrikterne og i egnene der grænser op mod Republikken, hvor IRA har forholdsvis let ved at operere, er overbeviste om, at de uden styrkens natlige patruljer og dens hårdhændede »advarsler« over for katolikkerne forlængst havde måttet flytte fra gård og hjem. For de mere afsidesboende protestanter er den tryghed og beskyttelse styrken yder den egentlige grund til, at enhver våbenfør mand er villig til, og moralsk forpligtet til at tage sin tørn med. Alligevel er det klart, når man ser på Nordirland som helhed, at B-specialkorpset ikke alene tjente til 
at beskytte staten og borgerne og til at skræmme katolikkerne. Rekrutteringen fandt fortrinsvis sted gennem Orangeordenen. Med en styrke på 10.000 mand i en provins med 40.000 arbejdsløse (hvoraf utvivlsomt mindre end halvdelen var protestanter) er det givet, at den økonomiske tjans det var at bruge nogle aftener som medlem af B-styrken fungerede som en belønning og dermed et incitament for militant loyalisme blandt protestanter af de laveste klasser.

Diskriminering ved ansættelser er også udbredt i den private sektor, men noget samlet talmateriale er ikke tilgængeligt. I småbyerne er den karakteristiske form for virksomhed det lille familieforetagende, der ledes af ejeren, er snævert integreret i det lokale samfund, og som drives på patriarkalsk vis. I hvert fald indtil midten af halvtredserne var denne virksomhedstype meget fremherskende i Nordirland, i skarp kontrast til resten af Storbritannien. Forholdet mellem antallet af familieforetagender og aktieselskaber afviger ikke meget fra gennemsnittet for Storbritannien som helhed, men familieejede virksomheder er langt større i Nordirland og tegner sig for en langt større del af den samlede kapital og arbejdskraft. Af den samlede kapitalmasse stod de privatejede selskaber for tre femtedele i Nordirland, sammenlignet med en trediedel i Storbritannien som helhed. Beskæftigelse i disse virksomheder er ofte et spørgsmål om tradition og personlig protektion. Mange stillinger opfattes næsten som et familieprivilegium og går i arv fra far til søn. For den der søger arbejde er det ofte nødvendigt at få »Mesteren« i den lokale Orange Loge til at lade et ord falde på rette sted. Forøvrigt bliver ledige stillinger, både i den offentlige og i den private sektor, ofte »opslået« fra mund til mund, så kun »den rigtige slags« søger. Dette sker på begge sider, men der er selvfølgelig meget længere mellem de ledige stillinger der er forbeholdt katolikker.

Den samlede arbejdsløshed har sjældent været under 7 pct. af de forsikrede arbejdere og har været langt højere i visse egne og fag. I Londonderry var arbejdsløsheden blandt mænd gennemsnitligt omkring 20 pct. op gennem tresserne, og i Strabane er 25 pct. typisk. Blandt katolikker og ufaglærte (der forøvrigt fortrinsvis er katolikker) er procenten selvsagt højere endnu. Arbejdsløshedstallene findes ikke fordelt efter religion, men i en by der blev undersøgt, i hvilken der er lige mange katolikker og protestanter, udgjorde de første 90 pct. af de arbejdsløse. Og i virkeligheden giver selv sådanne tal et alt for rosenrødt billede af forholdene, for mange katolikker bliver trætte af at vente i arbejdsløshedskøen og udvandrer i stedet. Groft regnet udvandrer en ud af hver tre katolikker (mænd og kvinder) og en ud af hver syv protestanter mellem deres 17. og 27. leveår. ${ }^{9}$ Det er klart at en stor del af forskellen mellem den protestantiske og den katolske udvandring må tilskrives katolikkernes større andel af de ufaglærte arbejdere, de fattigste bønder og af befolkningen i den vestlige, mindst udviklede del af

9. Dette kan have ændret sig i de senere år. Tallene er fra halvtredserne. 
Nordirland. Men forskellen er også resultatet af en mange steder åbent erklæret politik, der går ud på at holde katolikkernes antal nede. Dette er gået glat indtil for få år siden, eftersom den katolske andel af befolkningen har holdt sig næsten uforandret på 35 pct. siden 1920, til trods for et enormt katolsk fødselsoverskud. Det katolske fødselstal er næsten dobbelt så stort som det protestantiske.

Det fremgår af alt dette, at det er en afgørende forudsætning for at systemet kan fungere, at protestanterne ikke blot har magten i de lokale råd, men - for at korruption, små-privilegier og diskriminering skal kunne fortsætte uhindret at denne magt er total, permanent og uden nogen som helst forbindelse med den grad til hvilken det lokale styre opfylder eller undlader at opfylde de til enhver tid gældende vælgerkrav. Det var derfor nødvendigt at lave svindel med valgsystemet, således at Unionistpartiet var sikret et flertal i alle lokalråd og således at fraktionsdannelser i de Unionistiske rækker kunne afværges. Det første blev opnået ved at begrænse valgretten til ejere og lejere af fast ejendom og ejere af jord og anden beskattet ejendom, ved at give fra een til seks ekstra stemmer til selvstændige erhvervsdrivende i det distrikt, hvor deres virksomhed ligger, ved at ændre på valgdistrikternes afgrænsning, og i enkelte tilfælde ved udstrakt svindel ved urnerne. Den begrænsede valgret havde den dobbelte fordel at formindske de katolske stemmers vægt og at begunstige traditionelt konservative befolkningsgrupper som gårdejere i forhold til landarbejdere, og håndværkere og mindre forretningsdrivende i forhold til arbejdere. Når først valgdistrikternes grænser er valgt, sådan at de katolske stemmer er i mindretal i de fleste af de enkeltmandskredse der svarer til et givent lokalråd (det seneste tilfælde af en sådan ny grænsedragning med tydeligt politisk sigte var i grevskabet Fermanagh i 1967), så er diskrimineringen i tildeling af boliger og stillinger tilstrækkelig til at fastholde afstemningsmønsteret.

Det væsentlige at bemærke på dette sted er ikke, at systemet er »udemokratisk «, fordi der er visse steder, hvor et mindretal kan forblive ved magten. Det afgørende er at systemet er så stabilt og så stift, at åben korruption er mulig. og at det lokale styre er fuldstændig beskyttet mod enhver ydre kontrol, den være sig folkelig eller anden. Med et konstant flertal i lokalrådene tjener oppositionspartierne kun som vinduespynt, og det er rent faktisk et eet-partisystem. Den katolske opposition tvinges ud på gaderne, og den protestantiske opposition tvinges ind i Unionistpartiet eller i de orange organisationer, hvor det ville være dumdristigt af enhver, der har en bolig, et job eller en forretningsgoodwill at miste, at hæve stemmen for meget. Det er derfor kun i den relative anonymitet i en storby som Belfast, at et oppositionsparti har nogen mulighed for at tiltrække blot en brøkdel af de protestantiske stemmer.

Det er afgørende for systemet at forhindre splittelse blandt Unionistpartiets vælgere og fremvæksten af partier, der bygger på klasse- snarere end religionstilhørsforhold. Enkeltmandskredssystemet er et væsentligt led i opnåelsen af 
dette, og det er også de udstrakte pressionsmidler man har til at gennemtvinge konformitet. Ikke desto mindre er det næppe nogen overdrivelse at sige, at en nødvendig forudsætning for Unionisternes sammenhold var den bistand de fik fra katolsk side. Den trussel mod samfundsordenen, som katolikkerne i begge dele af Irland har udgjort ved deres vægring ved at anerkende Nordirland som en separat politisk enhed, er forblevet en troværdig trussel i hele den tid der er gået siden Irlands deling. Derfor kunne spørgsmålet om grænsens ukrænkelighed og om tilhørsforholdet til England trækkes frem igen forud for ethvert valg for at afværge alle splittelsestilbøjeligheder og overskygge alle mere jordnære politiske stridspunkter. For flertallet af borgere i Nordirland blev hvert eneste valg til en folkeafstemning for eller imod provinsens tilknytning til England. Det er næppe muligt at forestille sig, at orangevældet kunne have overlevet uden IRA's spredte angreb og uden den megen propaganda fra den Irske Republik om at delingen måtte få en ende. De militante udtalelser der kom fra syden, var fortrinsvis af retorisk art. Ikke desto mindre var denne retorik en politisk nødvendighed i syden, og den forstærkede sekterismen og undertrykkelsen i Nordirland og blev selv forstærket deraf. Der har således foreligget en mærkværdig de facto alliance mellem Unionisterne i nord og Fianna Fail (og andre partier) i syd, hvorved de er »enedes« om at holde delingsspørgsmålet i live og derved har hjulpet hinanden til begge at forblive ved magten. Det er katolikkerne der har måttet betale de direkte omkostninger i form af undertrykkelse. Men de indirekte omkostninger har været langt større og langt mere ligeligt fordelt, for denne tingenes tilstand har hindret en korrekt forståelse af situationen fra at opstå. Den totale og bedrøvelige mangel på klassebevidsthed og politisk organisation blandt irske arbejdere og de religiøse ideologier, som har haft overhånd, vidner om dette. Det vil senere blive berørt mere udførligt.

Den struktur, der ligger til grund for orangevældet, er selvsagt ikke enestående for Nordirland. Nære paralleller findes i andre samfund, hvor skyttegravene er ligeså dybe, hvor etniske eller racemæssige skel deler befolkningen, og hvor det politiske liv har sit tyngdepunkt i de små provinsbyer. I Mississippi, for eksempel, er der (eller var der indtil for nylig) den samme form for koalition af samtlige klasser, med det Demokratiske parti på den ene side og borgerforeningerne (Citizens' Councils) og Ku Klux Klan på den anden, i roller der ganske svarer til henholdsvis Unionistpartiets og Orangeordenens i Nordirland. I Mississippi finder man den samme dyrkelse af historiske myter (denne gang om tiden før borgerkrigen og genopbygningen), den samme patriarkalske ledelsesform med lokale »bosser « og den samme enhedsfront omfattende hele herskerracen, en front, der ikke bygger på enighed om politiske mål i den almindelige betydning af ordet politik, men på en ideologi om en naturlig herskerstilling, støttet af religiøs fundamentalisme og på en loyalitet, der om nødvendigt opret- 
holdes ved økonomisk pression, ved truslen om social isolation og undtagelsesvis ved voldshandlinger, der tjener som advarsel. Det er næppe heller noget tilfælde at udover Nordirland er de vigtigste områder hvor den oprindelige Calvinistiske og Wesleyanske religiøse fundamentalisme har overlevet Sydafrika, Østpreussen og de amerikanske Sydstater, alle kolonilignende nybygger- og grænsesamfund.

Både teoretisk og empirisk er der langt igen til en klar forestilling om denne type samfundsformation. Ikke desto mindre kan der være anledning til - med alle de nødvendige forbehold - at pege på nogle få særligt vigtige aspekter som synes at adskille denne art samfundsformation fra de borgerlige samfundsformationer vi er vant til, og i hvilke der er en udtalt dominans af en forholdsvis ren kapitalistisk sektor. I den »orange« samfundsformation, som man i mangel af bedre kunne kalde den, synes der at være en langt mindre grad af autonomi mellem formationens økonomiske, politiske og ideologiske niveauer. Det er således tilfældet, at de undertrykte klassers økonomiske kamp (f.eks. for bedre boliger eller beskæftigelse) ikke kan holdes inden for rammerne af det økonomiske niveau selv. Den økonomiske kamp har umiddelbare følger på det politiske niveau og er nødvendigvis samtidig en politisk kamp, fordi enhver økonomisk indrømmelse direkte undergraver orangevældets politiske magtstruktur. Det ser også ud som om de politiske og ideologiske niveauer har en mere dominerende rolle i forhold til basis, det økonomiske niveau, end tilfældet er for de mere vanlige kapitalistiske samfundsformationer. Det er sådan set kun rimeligt eftersom aristokratisk-feudale protektor-klient relationer nok er ligeså karakteristiske for denne samfundsformation som det klassiske kontraktforhold mellem arbejdssælger og arbejdskøber. De dele af samfundet hvor mere »rene« kapitalistiske produktionsrelationer har en mere fremtrædende plads - Belfast - er også de steder hvor organisering efter klassetilhørsforhold volder færre vanskeligheder, hvor ikke-sekteriske politiske partier har en vis tiltrækningskraft, og hvor reformistiske og fagforeningsorienterede ideologier, der er karakteristiske for arbejderklassen i borgerlige samfund, bedst har kunnet holde stand over for tilløb til sekteriske frontdannelser i arbejderklassen.

Det ideologiske niveau - det sæt af begreber ved hjælp af hvilke mennesker oplever deres tilværelse og tolker og sammenstiller deres erfaringer - synes at indeholde et betydeligt mål af aristokratisk-feudale bestanddele, selv om det naturligvis er dybt mærket af samfundets borgerlige karakter og ligeledes af de patriarkalske og (i ordets bredeste betydning) »racemæssige« former, som er typiske for tilflytterkolonierne. Denne forening af borgerlige og koloniale elementer viser sig i den »Herrenvolk-egalitarisme«, den ideologi (ikke at forveksle med en virkelighed) om lighed inden for herskergruppen, som man finder i Orangeordenen og i Unionistpartiets favnen af alle klasser. Men inden for det ideologiske niveau er det religiøse område dominerende (som det også er det i den feudale 
produktionsmåde) ${ }^{10}$ Dyrkelsen af traditioner og mytologier i andre områder af det ideologiske niveau - inden for moral og politik, forestillinger om national identitet, osv. - vidner om det religiøse områdes dominans. I andre borgerlige samfund er det religionen, som er blevet præget af de ideologiske områder, som var dominerende (især det politisk-juridiske område), ${ }^{11}$ og religionen er således blevet tænkt og oplevet i kategorier, der er afledt heraf (f.eks. vidner i disse samfund begrebet »religiøs frihed «, kirkens formelle uafhængighed af staten, der er en reel underordning og underkastelse, og det individualistiske og egalitære perspektiv på religionen om politisk-juridisk ideologiske kategoriers indflydelse). Dette er verdsliggørelsesprocessen, i hvilken den religiøse ideologi fratages sit sakrale indhold og sin karakter af at være et system af samfundsmæssige imperativer, reduceres til et sæt af private normer og indføjes i en underordnet stilling $i$ ideologien om et samfund af frie individer. I Nordirland, hvor religionen er forblevet ideologiens dominerende område, er den ikke blevet »smittet« på denne måde. Om noget er det de andre ideologiske områder, der er blevet smittet ved at blive tænkt i religiøse kategorier. Dette er grunden til at religionen ikke alene opleves langt stærkere i Nordirland, end den gør andre steder. Det er religionen selv, der er kvalitativt forskellig fra, hvad den har udviklet sig til andetsteds, f.eks. i England. Heraf dette, at fundamentalismen har kunnet overleve med dens samfundsmæssige elitisme og militante kristianisme. Heraf også irrelevansen af at studere irske forhold gennem de briller, der udgøres af vore ideologiske forestillinger om religiøs tolerance og om adskillelse mellem religion og politik.

Alt, hvad der her er sagt, har som nævnt i allerhøjeste grad yderligere uddybning og undersøgelse behov og må indtil videre forblive hypotetisk. Hensigten har kun været at antyde, at den nordirske samfundsformation ikke blot er det britiske borgerlige samfund tilsat diskrimination, religiøs lidenskabelighed og forfatningsmæssige stridigheder, men at hele denne samfundsformations struktur afviger radikalt fra, hvad vi er vant til, selv på de mest fundamentale områder, som de politiske, økonomiske og ideologiske niveauers indbyrdes autono$\mathrm{mi}$, den relative dominans mellem dem og overbygningens mere fremtrædende rolle. Der gives derfor ingen gradvis overgang gennem lovgivning om mindretalsrettigheder fra orangevældet til et samfund efter britisk model. Overgangen må nødvendigvis bestå i en omstøbning af hele den politiske, økonomiske og

10. Det skal fremhæves, at i begge tilfælde er denne dominans alene et spørgsmål om ideologisk tolkning. Man bør ikke opfatte det derhen, at de afgørende spørgsmål er af religiøs karakter. Den dominerende rolle i samfundsformationens bevarelse indtages, som bemærket, af en kombination af de ideologiske og politiske niveauer. Det er disse, der er bestemmende i de ideologiske kampe, der foregår, og i klassekampen i særdeleshed. Den ideologiske fremhævelse af religionen tilslører denne kendsgerning, men formår ikke at ændre den. Ejheller er påstanden om det religiøse områdes dominans på det ideologiske niveau ensbetydende med, at de spørgsmål, vi opfatter som sekulære, fremstår som spørgsmål af doktrinær karakter i Irland. Det drejer sig ikke om at søge svarene på samfundsmæssige og politiske problemer i de hellige skrifter. Det er ikke de ting, der tænkes, der er religiøse; det er måden, hvorpå de tænkes, der er.

11. Se Nicos Poulantzas: Pouvoir politique et classes sociales, Paris 1971, Bd. II, kapitel 2. 
ideologiske struktur, og er derfor en egentlig revolutionær overgang. De kampe, som har stået på i Nordirland siden 1968, vidner netop om denne forandrings revolutionære karakter og om den fuldstændige omordning af samfundet, den nødvendiggør. Den modsætning som ligger bag, og som giver sig udtryk i de igangværende kampe, er modsætningen mellem to uforenelige samfundssystemer: den orange samfundsorden, der kan opfattes som en paternalistisk eller »klientilistisk « udgave af en kapitalistisk samfundsformation, og det tyvende århundredes forvalter- og teknokratkapitalisme.

\section{Konvergens mellem Nord og Syd}

Ovenfor blev den orange samfundsorden beskrevet som et system, der byggede på et nært samspil mellem Orangeordenens loger, den lokale forretningsverden, Unionisternes partimaskine, det lokale styre og administrationen og de protestantiske kirkers hierarkier. Systemet blev opretholdt af diskriminering, protektorrelationer og frygten for virkelige og indbildte skræmmebilleder, som irsk selvstyre og pavevælde. En sådan fremstilling af systemets gennemførte konsekvens og stabilitet skal dog ikke få en til at overse de modsætninger, der er indbygget i det, og som før eller siden må føre til dets sammenbrud. To indbyggede årsager til instabilitet falder straks i øjnene: for det første har systemet så ringe modtagelighed over for tryk fra bunden og så stor evne til at flytte byrden af dets fejltagelser over på katolikkernes ryg, at det i stedet for at tilpasse sig til skiftende vilkår er tilbøjeligt til at lade spændingerne bygge op til bristepunktet. For det andet må systemet bære en dobbeltmaske, eftersom de koloniale og borgerlige elementer i dets ideologi er indbyrdes uforenelige: på en og samme tid må systemet fremvise undertrykkelsen og partiskheden åbent, og samtidigt må det ikke afvige for meget fra liberal ideologi - en balanceakt, det er så meget sværere at gennemføre, som staten ikke nyder fuld selvstændighed, men må tage hensyn til de ideologier, der er fremtrædende i England. Hvor vigtige disse to faktorer end har været for den senere tids begivenheder, er det dog den økonomiske udvikling på begge sider af grænsen, der har bidraget mest til at undergrave orangevældet.

Som man kunne forudse, indledte Sydirland straks efter delingen og borgerkrigen en protektionistisk politik. Toldafgifter blev indført mod sådanne britiske produkter, som, givet beskyttelse, ville kunne produceres rentabelt i Republikken. Dette medførte en eksplosiv vækst i industriproduktionen. Den steg med 30 pct., og beskæftigelsen steg med 40 pct. i de fire år fra 1932 til 1936. Men varerne var gennemgående dyrere og dårligere end de, der kunne købes på det internationale marked. Desuden betød hjemmemarkedets lidenhed, at grænserne for denne politik snart blev nået, hvorefter al import, der med fordel kunne erstattes med hjemmeproduktion, var blevet substitueret. Allerede i 1938 blev der ind- 
gået en første handelsaftale med England, og det var kun på grund af krigen og efterkrigsboomet, at den protektionistiske politik holdt sig yderligere 10-20 år. Tidligt i halvtredserne blev det igen bydende nødvendigt at opgive protektionismen for at kunne ekspandere på det internationale marked. Protektionismens grundlag, The Manufactures Act, blev ophævet i 1959, og i 1965 blev indgået en frihandelsaftale med England, ifølge hvilken alle toldafgifter skulle afvikles over en tiårig periode. Som et yderligere skridt henimod en konkurrencedygtig industri påbegyndtes efter 1954 et efterhånden meget omfattende system af låne- og skattebegunstigelser for at tiltrække udenlandske investeringer.

Økonomisk set er uionen mellem Sydirland og England således ved hurtigt at blive genoprettet, og den vaskeægte anti-imperialistiske periode blev aldrig til mere end en kort parentes. Samtidig med at frihandelspolitikken og bestræbelserne på at tiltrække engelske investeringer blev indført, blev forsøgene på at skabe et nationalt borgerskab, dvs. en uafhængig kapitalistklasse i Republikken og et fuldt diversifieret produktionsapparat i virkeligheden opgivet som uigennemførlige.

Også i Nordirland havde de økonomiske vilkår ændret sig efter 2. verdenskrig. De traditionelle industrier, lærredsfremstilling og skibsbygning, kunne ikke længere finde tilstrækkelige markeder udenlands, og de familieejede virksomheder havde utilstrækkelig adgang til kapital til at kunne modernisere og omlægge til nye produkter. ${ }^{12}$ For at afværge stagnation og tilbagegang begyndte man allerede i 1945 på den samme politik som i syden, med at tiltrække udenlandsk industri ved hjælp af finansieringsbegunstigelser. Tidligt i tresserne blev denne politik udbygget i et enormt omfang. På grund af denne de facto konvergens mellem Nord- og Sydirland på det økonomiske område har delingen selv, den militante genforeningsånd i syd og orangevældet i nord alle mistet deres eksistensberettigelse og deres eksistensgrundlag.

I det lange løb vil overgangen fra privatejede (dvs. familieejede) til anonymtejede selskaber (ofte drejer det sig ikke engang om selvstændige selskaber, men om datterselskaber af de store internationale koncerner) på afgørende vis svække grundlaget for den orange samfundsorden. De nye industrier er ikke i samme grad afhængige af velviljen hos det lokale fåmandsvælde de steder, hvor de slår sig ned, og fordi de ikke i samme grad er bundne til det lokale samfund, har de heller ikke de samme politiske ambitioner som de ældre virksomheder. Af samme grund er der mindre af et protektor-klient forhold til de ansatte og mindre tilbøjelighed til diskriminering ved ansættelser. Hvor der diskrimineres mellem katolikker og protestanter er det almindeligvis resultatet af beslutninger truffet i de enkelte værksteder snarere end af ledelsens politik, og sådan diskriminering har derfor ikke været helt så systematisk til fordel for protestanterne.

12. Se Isles and Cuthbert: An Economic Survey of Northern Ireland, H.M.S.O., Belfast 1957, særligt kapitlerne VIII og XI. 
Siden begyndelsen af halvtredserne har Nord- og Sydirland derfor stået over for nok så analoge økonomiske problemer og har søgt at løse dem på samme måde. Begge har søgt at udvide produktionen og undgå stigende arbejdsløshed ved at tilbyde eventuelle investorer finansieringsbegunstigelser, billig arbejdskraft og uhindret adgang til det britiske marked. For at bøde på manglen på tilstrækkelig efterspørgsel på hjemmemarkedet, som måske har været den alvorligste hindring for økonomisk ekspansion, indså begge regeringer nødvendigheden af større økonomisk samarbejde og integration mellems øens to halvdele. De første forsigtige samarbejdsskridt (der vedrørte jernbanetransport, kraftværker og fiskeri) blev taget i begyndelsen af halvtredserne.

Normaliseringen af de politiske relationer mellem Nord og Syd, i sig selv en forudsætning for effektive fremskridt på det økonomiske område, forudsatte at republikken i syd anerkendte den statsretlige status quo. Men dette måtte uvægerligt svække orangevældet yderligere ved at fratage det dets tilsyneladende eksistensberettigelse. Ydermere måtte diskrimineringen mod katolikkerne i nord ophøre eller i det mindste se ud til at være i aftagende, hvis regeringen i syd skulle finde politisk opbakning i befolkningen til at medvirke til en tilnærmelse. Det er i disse selvmodsigende krav man skal søge forklaringen på O’Neill-regeringens håbløse dilemmaer, dens patetiske retorik og dens stadige politiske vaklegang. I nord måtte katolikkerne overbevises om, at reformer var på vej, og dog måtte protestanterne samtidig overbevises om det modsatte, hvis ikke regeringen skulle tabe sin støtte blandt de Unionistiske vælgere og de lokale bosser.

Den velfærdspolitik som efterkrigstidens labourregeringer i England påbegyndte, bidrog også til at undergrave den gamle samfundsorden i Ulster. Grundlaget for velfærdspolitikken i England har været den vidtgående autonomi mellem samfundsformationens økonomiske og politiske niveauer: økonomisk eftergivenhed over for de undertrykte klasser kunne finde sted uden direkte at true den politiske orden. ${ }^{13}$ I Nordirland var der imidlertid ikke en sådan autonomi: såkaldt »fair « ansættelsespraksis, »lige « adgang til uddannelse, »fuld « beskæftigelse osv. ville have konsekvenser langt ud over det økonomiske område. Flere boliger, mindre arbejdsløshed og større understøttelse ville mindske strømmen af katolske emigranter og på længere sigt undergrave det protestantiske flertal. Bedre adgang for katolikkerne til uddannelse og til offentlige og private topstillinger ville inddrage dem i overklassen, give dem en større magt i samfundet, men også gøre dem mere loyale over for det, faktorer, der igen ville undergrave protestanternes absolutte herredømme i småsamfundene. Når derfor Unionisterne i Nordirlands parlament i Stormont efter krigen fortsatte »skridt for skridt« politikken, der gik ud på at kopiere den lovgivning 
der blev gennemført i London (mere eller mindre), til gengæld for at Londonregeringen afstod fra at blande sig i nordirske anliggender, så gravede de deres egen grav. Virkningen af den almindelige sygeforsikring, af familietilskud, af statsstøtte til uddannelse osv. var at mindske udvandringspresset på katolikkerne, beskytte dem mod systemets værste vinterkulde, skabe grundlaget for fremvæksten af en katolsk middelklasse, og, ved at give Nordirland et forspring over for Republikken hvad velfærds- og socialpolitikken angik, at dæmpe begejstringen i nord for en genforening under Dublinstyret. Alle disse forhold udgjorde direkte angreb mod selve orangevældets grundvold.

\section{Den politiske kamps former}

Det historiske forløb af den politiske kamp i Nordirland siden 1968 turde være velkendt $\mathrm{i}$ hovedtræk, og der er $\mathrm{i}$ hvert fald ingen mening $\mathrm{i}$ at opsummere det her. Det der er behov for er noget andet, nemlig en analyse af den politiske kamps former for at vise, at disse faktisk er »afspejling « eller »fremtrædelsesform« for den tilgrundliggende modsætning mellem den gamle og den nye samfundsorden, og at denne modsætning fuldt ud kan gøre rede for begivenhederne. Uden denne efterprøvelsesprocedure må de ovenfor fremførte påstande om karakteren af den modsætning, der er det teoretiske udtryk for de seneste års kampe, i et vist mål forblive rene spekulationer. En sådan undersøgelse ville imidlertid blive så omfattende, at den langt ville overskride denne artikels rammer. Derfor skal jeg på dette sted nøjes med at pege på det meget komplekse forhold, der er mellem modsætninger og de kampe de afføder, og ganske kort opridse, hvordan det kan gå til, at modsætningen mellem den gamle og den nye samfundsorden har givet sig udtryk i netop de kampformer, man har observeret i konfliktens skiftende faser.

Jeg har hævdet, at den nuværende konflikt er fremtrædelsesformen, sådan som den tager sig ud på det politiske niveau, for overgangen fra en variant af en kapitalistisk samfundsformation til en anden. I Nordirland finder man på indeværende tidspunkt en kombination af de to samfundssystemer indeholdende elementer fra begge, men uden at nogen af dem klart dominerer det andet. Den samtidige eksistens af disse elementer giver anledning til modsætninger inden for alle samfundsformationens niveauer - det politiske, det ideologiske, det sociale, det økonomiske osv. - fordi den nye orden uundgåeligt undergraver den gamle (det er derfor der er tale om en modsætning) på hvert af disse niveauer og på måder, der allerede er blevet omtalt. Kampe (i dette ords videste betydning) udspiller sig på hvert niveau, og deres karakter er forskellig alt efter hvilket niveau, man betragter. På det politiske niveau viser disse kampe sig ved gruppedannelse, mobilisering af masserne, kamp om hver af statsmagtens forskellige komponenter (politi- og ordensstyrker, kommunernes beføjelser, Londons 
beføjelser, valgsystemet, undervisningssystemet osv.), konfrontation i gaderne m.m.; det ideologiske niveaus kampe fremtræder for det meste som visse overbevisninger og rationaliseringer, der tjener til at forlige uforenelige ideologier eller til at kontrastere dem. Kampen på hvert niveau er ikke alene bestemt af modsætningernes særlige karakter på dette niveau, men også af kampens udvikling på de andre niveauer og af de historisk specifikke bestemmelser, der gør sig gældende på det tidspunkt, hvor modsætningerne opstår og skærpes.

Teoretiske modsætningers »afspejling « i de aktuelle politiske kampe er derfor en yderst sammensat og indirekte formidling. Ideologiske rationaliseringer påvirker den politiske kamp og er selv påvirket af den. I princippet måtte en analyse af den politiske kamps former betragte alle disse niveauer under eet og holde rede på deres gensidige bestemmelser og på den måde hvorpå kampen på et niveau »forvrider « kampen på alle andre niveauer. Forenklede antagelser om en parallelisme mellem de forskellige niveauer eller den vulgær-marxistiske forestilling om, at alt er en forholdsvis direkte »afspejling " af det økonomiske niveau, er helt uden grundlag. De alliancer, som faktisk opstår på et givet tidspunkt i kampen, er ikke et mere eller mindre direkte udtryk for klassers eller klassefraktioners objektive interesser i forhold til de tilgrundliggende modsætninger. Såkaldt »falsk bevidsthed « er allestedsnærværende i denne form for konflikt. I tilfældet Nordirland er det fordi man har undladt at tage hensyn til disse bestemmelsers kompleksitet, fordi man altså har troet, at hovedfrontlinien svarede direkte til hovedmodsatningen, at man, da det nu engang er her fronterne går, har søgt den grundliggende modsætning i forholdet mellem irsk og britisk (repræsenteret af hæren), som mange irere gør det, eller i forholdet mellem katolikker og protestanter, som mange briter gør det.

Det er heller ikke en almengyldig regel, at når modsætningerne skærpes, så bliver alliancer, gruppedannelser og politiske målsætninger mere entydige udtryk for objektive klasseinteresser og kampene mere direkte gengivelser in concreto for de teoretiske modsætninger. I Nordirland er det det modsatte, der er sket, og årsagen er let at forstå. Efterhånden som modsætningerne skærpes, bliver niveauernes indbyrdes vekselvirkning snævrere, konsekvenserne af kampen på et niveau for kampene på andre niveauer bliver mere direkte og udtalte. Og i betragtning af forholdene i Nordirland, og især af den totale forvirring og forfalskning på det ideologiske niveau, har det med tiden ført til et mere, ikke et mindre komplekst forhold mellem modsætninger og de kampe, de kommer til udtryk i. Dette fremgår bedst, når man ser på begivenhederne så langt tilbage som begyndelsen af tresserne.

Den nye økonomiske politik i nord og dens nødvendige vedhæng i form af spæde forsøg på en udsoning med katolikkerne tog fart efter 1963, da O’Neill overtog premierministerposten. På dette tidspunkt begyndte slagordet »O'Neill 
must go« at dukke op på protestantiske husmure, og en begyndende samling fandt sted omkring pastor Paisleys angreb på regeringens relativt moderate politik. I denne fase af konflikten vakte den ikke megen opmærksomhed uden for Nordirland, men dens grundlag fremgik allerede klart: det var en konflikt mellem protestanter. Tilsyneladende stod striden om den politik, der skulle føres over for Republikken og over for katolikkerne i nord. Men dybere set var det en konfrontation mellem to uforenelige opfattelser af den fremtidige politiske, økonomiske og samfundsmæssige orden i Nordirland.

Katolikkerne spillede ikke nogen nævneværdig rolle før »Campaign for Social Justice« dukkede op i 1966-67. Den havde sin oprindelse i de katolske professionelle lag, som efterkrigstidens udvikling på det økonomiske og uddannelsesmæssige område og udbygningen af velfærdsstaten havde bidraget til at skabe og styrke. Dens direkte forbindelse med fremvæksten af en moderne kapitalisme i Nordirland fremgår allerede af bevægelsens afvisning af de traditionelle katolske Republikanske og Nationalistiske ideologier til fordel for en liberal ideologi med tryk på »borgerrettigheder« og »social retfærdighed«. Det er betegnende, at Kampagnen søgte at nå sine mål ved at appellere til engelske politikere og engelsk offentlig mening, hvorved den åbent viste, at kampen var rettet mod Orange- og Unionistoligarkiet og hele det system, de stod for, ikke, derimod, mod tilknytningen til England. Objektivt såvel som subjektivt var bevægelsen på samme side som de moderate og reformisterne i og omkring regeringen i Befast.

Den gamle ordens vogtere blev således engageret i en tofrontskrig, i hvilken pression og trusler måtte rettes både mod katolikkerne og mod regeringen. Den mobilisering af de katolske masser omkring borgerretsbevægelsen, som fandt sted i løbet af 1968, var først og fremmest resultatet af disse provokationer fra protestantisk side.

Denne mobilisering havde meget betydelige ideologiske virkninger, fordi den ved simpel fortynding svækkede de professionelle lags indflydelse på de militante katolikker. Som bevægelsen voksede, ændredes tyngdepunktet for dens politik og dens ideologi fra den bedrestillede middelklasses krav om liberalisering og deres egen ligestilling med protestanter inden for rammerne af den nordirske statsdannelse til de katolske massers traditionelt Republikansk-Nationalistiske og mere venstreorienterede standpunkt, hvorved tiden, i det mindste subjektivt, blev skruet tilbage til det gamle mønster af nationalitetskamp med sekteriske overtoner. Katolikkernes ændrede holdning til de engelske tropper kort efter deres ankomst i august 1969 var en følge af denne ændrede sammensætning af den militante sektor blandt katolikkerne. De med denne forskydning af den politiske kamp forbundne ideologiske transformationer diskuteres mere indgående senere.

Den reformistiske og "progressivt demokratiske« del af den katolske opinion, den højere middelklasse, forsvandt ikke fra den politiske scene, men ved 
at miste det politisk-ideologiske lederskab på den katolske side er den blevet skåret tilbage til sin sande politiske betydning. Som tilsvarende grupper på protestantisk side udgjorde denne gruppe aldrig det moderate og indtil videre tavse flertal, som den engelske regering og presse i årevis har sukket efter. I virkeligheden har de moderate middelklasseelementer hele tiden udgjort et overordentlig højrøstet mindretal. Sammen med ligesindede protestanter findes denne gruppe nu omkring det nystartede Allianceparti og lignende politiske dannelser. Disse gruppers ekstreme politiske svaghed, der anskueliggøres ved at Unionistpartiets ledere på grund af modstand i partiets lavere rækker har været ude af stand til at gennemføre deres program, har sit modstykke i deres dominerende stilling i den økonomiske konfrontation. Kampen på det politiske niveau har været bagud for kampen på det økonomiske niveau, og det er dette, der har givet anledning til den manglende politiske stabilitet i Nordirland i de seneste år. Det direkte styre fra London, som blev påtvunget i foråret 1972, vil uden tvivl mindske dette efterslæb ved yderligere at afskære de katolske og protestantiske masser fra reel politisk indflydelse. Som sådant fremskynder det den overgang til den nye orden, som må komme i alle tilfælde. Til trods for deres nuværende svaghed vil den bedre middelklasses politiske organisationer, som f.eks. Alliancepartiet, derfor sandsynligvis vinde i indflydelse i løbet af de kommende år. Deres socialdemokratiske eller labouragtige politisk-økonomiske perspektiver (demokratiseringsreformer, støtte til industrielle storforetagender, økonomiske indrømmelser til arbejderne når og hvis "provinsens økonomi« og konkurrenceevne tillader det) svarer til et muligt kompromis mellem de højere funktionærer og professionelle, storkapitalen og arbejderbevægelsen. Efterhånden som orangevældet bryder sammen, og den socialistiske revolution, som venstrefløjens militante drømmer om, viser sig ikke at blive til noget, kunne denne politik i stigende grad vise sig at svare til disse forskellige gruppers øjeblikkelige politiske og økonomiske behov.

Indtil slutningen af 1969 havde orangevældets tilhængere formået at udvande eller helt at forhindre de lovede reformer, og medens regeringen kom med løfter på en række områder, skete der i virkeligheden meget lidt. Herved opstod en kløft mellem katolikkerne og Belfast-regeringen (og sidenhen den britiske regering) efter at også denne havde fået placeret sig selv i den samme situation af velmenende magtesløshed. Derved lettedes også IRA's overtagelse af den ideologiske og taktiske ledelse.

I den første fase blev resultatet en trekantskonfrontation mellem katolske og protestantiske arbejdere og småfolk og britiske tropper, hvor stadigt tiltagende gadeoptøjer og voldshandlinger og voksende pres fra begge sider tvang den britiske og den nordirske regering til at indtage en ækvilibristrolle som »mægler « mellem hinanden bekrigende grupper, en rolle, som kun efterlod liden plads 
til politiske initiativer og effektiv intervention. På overfladen kom situationen derfor til at ligne en sekterisk krig med de britiske tropper i en politisk set passiv rolle i midten, hvor de blot syntes at følge den mindste modstands princip.

Dette er stadigvæk realiteterne bag overfladen, uanset den tilsyneladende beslutsomhed bag hjemsendelsen af det nordirske parlament og den britiske regerings overtagelse af styret. Den britiske hær og regerings formål er hverken at forhindre eller at fremme ændringer i Nordirlands politiske vilkår og forfatningsmæssige opbygning. Deres hovedmål er at neddysse hele redeligheden. I forhold til dette mål har britiske særinteresser i Nordirland kun underordnet betydning. I den nationale kamp, som finder sted - men selvfølgelig ikke i en egentlig socialistisk kamp, hvis der havde været en sådan - kan de britiske myndigheder betragtes som værende ligeglade. Men ligegyldighed er ikke det samme som neutralitet. Ligegyldighed over for udviklingen betyder nemlig netop, at man som en vejrhane retter sig ind efter det største tryk. Det er i denne forskel mellem neutralitet og ligegyldighed, mellem en politik og manglen på en politik, at man kan finde grunden til IRA's håb, til protestantiske loyalisters frygt og til de britiske »fredsbevarende styrkers« ensidigt repressive karakter.

\section{Orangevaldets forsvarere}

I over et halvt århundrede har orangeismen, unionismen og protestantismen været så snævert forbundne elementer af den orange samfundsordens ideologi, at de på det nærmeste blev betragtet som synonyme. Ikke desto mindre er det nødvendigt at adskille disse begreber skarpt fra hinanden, eftersom de historisk set ikke altid har optrådt sammen. Ikke nok med det: i den nuværende situation med dybtgående splittelser på kryds og tværs af samfundet er de forskellige kræfter, som bidrog med hvert sit aspekt til de nordirske protestanters ideologiske begrebsverden, ikke længere i samme grad ensrettede, men trækker snarere i hver sin retning. Forstår man dette, så bliver det klart, at der ikke er noget virkeligt paradoks $i$, at protestanterne fra Shankill Road, under britiske bannere og under påberåbelse af loyalitet over for dronningen, går til angreb på Hendes Majestæts soldater.

Et system hvor der diskrimineres mod katolikker, kan ikke af den grund uden videre antages at være til fordel for protestanterne. På meget kort sigt og forsåvidt angår enkeltindividers konkurrence om f.eks. et bestemt job kan det meget vel være tilfældet, men i et videre perspektiv, og givet den socioøkonomiske struktur i Nordirland, kan det modsatte være nærmere sandheden: splittelsen af arbejderklassen og af småborgerskabet på sekterisk grundlag, den nemme adgang til en syndebuk for ethvert onde, den faktiske, om ikke juridiske, politiske umyndiggørelse af alt småfolk, protestantisk ligesåvel som katolsk, 
og den politiske atmosfære af uafbrudt undtagelsestilstand har alle bidraget til at svække kravene om samfundsmæssige reformer på ethvert område, og når alt kommer til alt, har det været lige så skadeligt for flertallet af protestanter, som det har været for katolikkerne. Elendigheden i de protestantiske slumkvarterer i Shankill Road turde være bevis nok.

Strukturændringen i økonomien i retning af moderne kapitalintensive industrier har været til fordel for visse grupper faglærte arbejdere, for teknikere, ingeniører og for andre højtuddannede, men ande grupper, ikke mindst de ufaglærte arbejdere, har måttet betale prisen i form af forringede beskæftigelsesmuligheder. Også den lavere middelklasse, bl.a. mindre, selvstændige erhvervsdrivende inden for handels- og servicesektorerne har været blandt taberne. Mange små butikker gik nedenom og hjem, da de engelske kædeforretninger rykkede ind i midten af tresserne. Mange gader i Belfast frembyder et trist syn af små butikker, der er blevet forladt og som aldrig kommer til at åbne igen. Det er givet, at en væsentlig del af den egentlige protestantiske aktivisme, af de »tartan gangs « af unge, der er lidet politiserede, men altid villige til et opgør med "papisterne«, udgøres af disse grupper af arbejdsløse, af ufaglærte, der kun har socialkontoret i udsigt, og af forhenværende småhandlende, som er blevet tvunget ud på arbejdsmarkedet, hvis de da ikke har emigreret.

Men det ville være en alvorlig fejltagelse at tro, at protestanternes uforsonlige kerne blot er en sådan samling vildledte »lumpen-sektorer « af det protestantiske småborgerskab og proletariat. Aktivistbanderne er kun isbjergets synlige del. Ärsagen til at deres vrede giver sig udtryk netop i kamp- og voldshandlinger, skal utvivlsomt søges i disse de-klasserede gruppers særlige plads og vilkår i samfundet, men for vreden selv må årsagen søges andetsteds, for den deler de med hele den protestantiske underklasse. Det tavse moderate flertal eksisterer ikke; flertallet er tavst, men ikke moderat. Aktivisterne er en ægte fortrop for de protestantiske masser: kun deres udtryksform er en anden; budskabet er det samme.

Det er en ideologisk set bekvem, men i politisk-strategisk henseende katastrofal fejltagelse katolske nationalister begår ved at overse dette forhold, som det også viste sig under kampene i forbindelse med Irlands deling i begyndelsen af århundredet. Unionisme og anti-katolske følelser henter den protestantiske arbejderklasse hverken fra den herskende klasse eller fra lumpenproletariatet, men fra dens egen objektive situation. Vi vender tilbage til denne blinde plet $\mathrm{i}$ de katolske nationalisters opfattelse af deres modstandere efter et forsøg på at redegøre for baggrunden for den protestantiske ekstremisme.

Først må man vel minde om de mere overfladiske ideologiske faktorer. De protestantiske masser i Nordirland har fået at vide, at deres ofte elendige og altid usikre tilværelse er en privilegeret tilværelse, og er blevet opflasket i den tro, at deres rettigheder og deres frihed var under angreb, og at de en dag kunne 
blive kaldt under våben for at forsvare den, som deres forfædre var blevet det i 1690 i slaget ved Boyne, i begyndelsen af dette århundrede, da de kæmpede for Unionen, og ved mange andre lejligheder. Efter 1969 syntes selv deres regering at have givet efter for dem, den selv beskrev som »revolutionære og undergravende elementer, der har søgt at tilintetgøre statens forfatningsmæssige rammer«. I flere år havde regeringen sagt og gentaget, at medens lovede reformer ville blive gennemført, så havde man nu imødekommet alle rimelige krav, og at ingen yderligere indrømmelser ville blive givet. Men kort efter sådanne højtidelige løfter så man regeringen endnu engang give efter for borgerretsbevægelsens og den engelske regerings fælles pression. Gårsdagens »uacceptable krav« blev morgendagens officielle politik, samtidig med at en ny grænse blev draget, som man svor aldrig at ville overskride. Naturligvis blev man på Shankill Road mere og mere overbevist om, at regeringen i en eller anden tåget forstand var en del af et republikansk komplot. Reformerne blev ikke anskuet - og kunne ikke anskues - som positive skridt mod en ny og bedre fremtid for Ulster, men kun som en endeløs række af forræderier. Det var regeringen selv, der fik dem til at tage sig sådan ud på grund af dens modstræbende tomme-for-tomme holdning og dens fremstilling af borgerretsbevægelsen som subversiv og republikansk.

Protestantiske arbejdere, småbønder og den lavere middelklasse er ikke uden videre modstandere af enhver reform, men de ser i borgerretsbevægelsen en IRA- og Republikanskinspireret sammensværgelse, hvis endemål ikke er opnåelse af lige rettigheder, men at løbe den nordirske stat over ende: sålænge flertallet af katolikkerne er Nationalister, må det indre forsvar af staten opretholdes. Den voldsomme modstand mod afvæbningen af politiet, mod opløsningen af B-specialstyrken og mod regeringens gradvise kapitulering over for England (fra troppernes ankomst i august 1969 til den fuldstændige magtafgivelse i marts 1972) var en logisk konsekvens af dette synspunkt, der, som vi har set, i alt væsentligt er korrekt. Den nordirske stat er alvorligt truet, og England er den mest upålidelige allierede, man kan tænke sig, som England også var det ved tidligere lejligheder (bl.a. under kampen om selvstyre i begyndelsen af århundredet og under den sidste krig, da Churchill var rede til at opgive Ulster som pris for Republikkens indtræden i krigen). I virkeligheden er England mere end upålidelig: England er en af hovedkræfterne i sammensværgelsen for at genforene Irland. Uden dets orange kampstyrke er Nordirland forsvarsløs. ${ }^{14}$

Uden forbundsfæller og givet den afgjorte mulighed, at Nordirland absorberes i en katolsk-Nationalistisk stat, er det ikke overraskende, at private protestantiske forsvarsorganisationer dukker op. Ved forskellige lejligheder har der

14. På det seneste har man selvfølgelig set den engelske hær optræde i en Orange vigilantestyrkes rolle som beskytter af staten i nord mod katolikkernes angreb. Men der er ingen sikkerhed for, at det vil fortsætte. Når og hvis IRA standser sine angreb, vil den britiske regering igen blive en fuldkommen upålidelig allieret for Nordirlands protestanter. 
endog været talt om en ensidig uafhængighedserklæring efter Rhodesisk mønster. Tanken er nok latterlig, om ikke andet så fordi Nordirlands økonomiske situation ikke er til det, men den er et symptom på fremvæksten af en stedse mere militant nordirsk protestantisk nationalisme.

Denne protestantiske nationalisme er ikke noget nyt fænomen, men den er ikke tidligere trådt tydeligt frem, fordi den fandt udtryk i Unionismen sålænge sammenslutningen med England endnu var den bedste garanti for Nordirlands uafhængighed af syden. Den viser sig derfor som en delvis anti-britisk kraft, nu hvor Englands loyalitet ikke længere kan tages for givet. I modsætning til den loyalitet, der grundedes i forretningsinteresser, og som vi ikke skal komme tilbage til her, har Unionisternes politisk og følelsesmæssigt bestemte loyalitet over for England altid været en modsætningsfyldt affære og ofte haft en hul klang, fordi den aldrig hvilede på en positiv fællesskabsfølelse over for England og engelske institutioner. Den var en reaktion mod irsk-katolsk nationalisme og havde i sig elementer af en selvhævdende kolonialistideologi, udklædt som Unionisme. Selv om det er sandt, at Nordirland aldrig bad om at få sit eget parlament, har parlamentet i Belfast både udtrykt Nordirlands ikke-britiskhed og forstærket den.

Over for tilhængerne af den hidtidige orange-dominerede samfundsorden er der næppe nogen mening $i$ at agitere for mådehold, indrømmelser, reformer og forsoning. At tale til »fornuften« er meningsløst, når ekstremisme er den mest forstandige politik, og når fornuften selv tilsiger, at den mindst udsigtsløse politik er at øve størst muligt pres på regeringen i London og true med at starte en borgerkrig. Protestanterne har med rette forstået, at de er under belejring og ikke kan forlade sig på andre end dem selv. Deres tro på, at enhver indrømmelse over for katolikkerne eller over for myndighederne i London og i Belfast med tiden vil blive brugt imod dem, er fuldstændig korrekt. Det fremgår allerede af, hvad der er sagt om reformernes indvirkning på den orange samfundsordens grundlag, og det vil fremgå endnu tydeligere, når vi sidenhen må konstatere hulheden i meget af den katolske retorik om solidaritet mellem arbejdere på tværs af religionsskel.

Men de fattige protestanters oprør og deres modstand mod reformprogrammerne må også forstås i lyset af den moralske og samfundsmæssige isolation, som er blevet disse folk til del. Snarere end et bevidst forsøg på pression på myndighederne er protestanternes oprør en fortvivlet reaktion fra mennesker, som er blevet svigtet og forkastet af alle, og som ikke kunne finde sympati, forståelse eller tilhørsforhold nogetsteds. Deres regering, Republikken, England og dets hær, pressen, radioen og fjernsynet, alle foragtede dem, alle pegede fingre af dem, alle betragtede dem som reaktionære og racister, og alle gjorde dem ansvarlige for Irlands endeløse religionskrige. Da den nordirske politistyrke, RUC, blev afvæbnet og B-specialstyrken hjemsendt, var forsvaret af Nordirland, og dermed selve dets fremtid som selvstændig enhed, overladt til de mennesker 
folkene i Shankill - med rette - havde lært at mistro mest af alle: regeringen i London. Omkring det eneste, som derefter kunne forene beboerne på Falls Road og på Shankill Road, var et fælles had til den engelske hær, som begge følte sig forrådt af, og som ingen følte sig beskyttet af.

Orangeblokkens styrke ligger $\mathrm{i}$, at den er et væv af forskellige tråde: de lokale orange magteliters selvopholdelsesdrift, en solid og velforstået interesse i alle protestantiske samfundslag (og også i store dele af den katolske gruppe) i at opretholde tilknytningen til England, frygten for at blive et mindretal i en katolsk-domineret genforenet irsk republik, et netværk af sølle privilegier og etablerede rettigheder, og en protestantisk (nordirsk og anti-britisk) nationalisme, der bliver mere og mere mærkbar, men først og sidst den protestantiske arbejderklasses og lavere middelklasses frygt og moralske isolation og den antikatolske holdning de giver sig udslag i.

Det er ligeså ubestrideligt, som det er velkendt, at fjendtlighed og intolerance over for katolikker er særlig fremherskende blandt protestanter af de lavere klasser, og det er da også fortrinsvis i arbejderkvartererne i Belfast og Londonderry, at de seneste års uroligheder har fundet sted (ligesom urolighederne hele vejen op gennem det nittende århundrede). Som nævnt er det blandt protestantiske arbejdere, småbønder og den lavere middelklasse, at Orangeordenen henter sin styrke, og det er også her, at først pastor Paisley og Ulster Protestant Volunteers og sidenhen Ulster Volunteer Force, Ulster Defence Association og William Craig's Vanguard-bevægelse har fundet støtte. Det er ganske åbenlyst, at det er i arbejderklassen, at anti-katolske holdninger kommer stærkest til udtryk, at det fortrinsvis er dér, modsætningsforholdet giver sig udslag i voldshandlinger, ${ }^{15} \mathrm{og}$ at det fortrinsvis er dér, man ustandseligt er på vagt over for enhver, der kunne tænkes at svigte protestanternes sag.

Men lige så åbenlyst er det, at det også er i arbejderklassen, blandt småbønderne og i den lavere middelklasse, at man finder en daglig kammeratlig omgang med katolikker, at man kender katolikker personligt og har et personligt, ikke blot et forretningsmæssigt forhold til dem. Derimod er en sådan personlig kontakt med katolikker en næsten ukendt foreteelse i de bedrestillede lag af samfundet. ${ }^{16}$ Skulle det endelig ske, at en af de mere velstillede protestanter har en katolsk bekendt, så viser det sig gerne, at det er en person, der er helt atypisk for katolikkerne i almindelighed, en slags »overløber«, der til gengæld kun har

15. Det er nok på sin plads at minde om, at der er tale om et generelt »kulturmønster«. Også mellem folk af samme religion er voldshandlinger langt hyppigere i arbejderklassen end i middelklasen. Men dér har man jo også andre kampmidler til rådighed.

16. Jvf. for landdistrikternes vedkommende Rosemary Harris: Prejudice and Tolerance in Ulster, Manchester University Press, 1972, s. 183-84, som jeg også i det følgende gør udstrakt brug af. Queens University i Belfast er nok den eneste betydningsfulde »blandede« institution for middelklassen. Det er næppe noget tilfælde, at det var studenter herfra, der under betegnelsen People's Democracy kom til at indtage en ledende rolle i borgerretsbevægelsens tidligere faser. 
ringe forbindelse med sine egne trosfæller. Denne »nærhed « mellem katolikker og protestanter i de lavere samfundslag kommer blandt andet til udtryk i det forhold, at fagforeningerne hører til de eneste organisationer med blandet medlemskab og - hvor det ikke er tilfældet - med et nært samarbejde mellem rent protestantiske og rent katolske afdelinger. ${ }^{17} \mathrm{Og}$ på de arbejdspladser, der beskæftiger både protestanter og katolikker - ikke mindst på de store skibsværfter - har arbejdet på »fabriksgulvet« været næsten totalt upåvirket af urolighederne, bomberne og terroren i gaderne udenfor.

Findes intolerancen og fordommene i bunden af samfundet, så er det også dér, at samarbejdet og den personlige kontakt mellem trossamfundene er at finde, dér man har erfaring i at omgås folk af den anden tro og ved, hvordan man skal undgå de samtaleemner, de utilsigtede hentydninger, de handlinger og de ord, der skaber splid, og dér man kan møde en udbredt solidaritet og en slags forsigtig tillid på tværs af religionsskellet, ikke blot mellem arbejdskammerater, men også - når man da ikke lever i gettoer - mellem naboer. Denne forholdsvis nære personlige kontakt og det til daglig nok forsigtige, men dog stort set gnidningsfrie forhold mellem katolikker og protestanter af de lavere samfundslag er ligeså meget - og måske langt mere - en del af den nordirske virkelighed som det latente modsætningsforhold, der undertiden bryder frem. Den konstatering er afgørende, fordi den tvinger en til at forkaste (i hvert fald for Nordirlands vedkommende - og sikkert også i mange andre tilfælde) de fleste af de »teorier «, der i tidens løb er fremsat for at »forklare« denne eller hine arbejderklasses fjendtlighed over for afvigende etniske, religiøse eller racemæssige mindretalsgrupper.

Blandt sådanne utilstrækkelige »forklaringer « er den hyppigst fremførte den, man kunne kalde den »liberale teori«, ifølge hvilken forskellige gruppers større eller mindre fjendtlighed over for udenforstående hænger nøje sammen med en utilstrækkelig kontakt mellem grupperne: Mistillid og fordomme kommer man til livs ved, at skoler og andre lignende institutioner integreres, og ved at al segregation og forskelsbehandling gradvist bringes til ophør. Dette har været den dominerende tankegang i den engelske presses kommentarer og blandt "progressive« og »moderate« protestanter i Nordirland. En anden populær »teori« er forestillingen om, at arbejderklassens »racisme« har et økonomisk-socialt grundlag, således at den protestantiske arbejder nægter katolikkerne ligestilling for at opretholde sin egen sociale status og sine egne økonomiske og sociale privilegier. Der er her forskellige varianter: forestillingen om et privilegeret »arbejderaristokrati« på den ene side og, hvor et sådant ganske åbenbart ikke findes, forestillingen om »the poor white«: den forarmede, foragtede og undertrykte sydstatshvide, der må holde de sorte endnu et trin under sig for dog at bevare

17. Jvf. Barritt and Carter: The Northern Ireland Problem, Oxford University Press, 1962, s. 140-42 (2. udg., 1972), samt Andrew Boyd: The Rise of the Irish Trade Unions 1929-1970, Anvil Books, Dublin, 1972. 
den sidste pjalt af sin selvrespekt. Når de skal forklare den protestantiske arbejderklasses manglende solidaritet med deres kamp, er det forklaringer som disse, at irske katolikker oftest tyer til. Endelig er der den vulgær-marxistiske »teori«, der henfører konflikter mellem arbejdere til kapitalens mere eller mindre bevidste forsøg på at så splittelse.

»Teorier« som disse kan nok henlede opmærksomheden på faktorer, der har eller har haft betydning for udviklingen af protestanternes ideologi, ${ }^{18}$ men de formår ikke at gøre rede for den overordentligt komplekse blanding af tillid og frygt, af tolerance og bigotteri, af samarbejde og strid hvormed den protestandiske arbejder møder katolikken. En dybere forståelse af nuancerne i arbejderklassens »racisme« forudsætter, at man betragter denne klasses samlede økonomiske, politiske, sociale og ideologiske situation, ikke blot i forhold til den ene modstander, som den katolske arbejderklasse udgør, men også, og samtidigt, i forhold til samfundets øvrige klasser, først og fremmest det protestantiske »establishment«. Etniske, religiøse og racemæssige modsætningsforhold - og det gælder i Nordirland ligesåvel som i USA, i England og alle andre steder - kan måske kortlægges, men de kan ikke analyseres som fritsvævende »fordomme«, løsrevet fra de ideologiske strukturer de indgår i, herunder holdningerne til andre samfundsgrupper, og løsrevet fra samfundets øvrige modsætninger og konflikter.

Ambivalens er, som det allerede er fremgået, det grundliggende træk ved den protestantiske arbejderklasses og lavere middelklasses forhold til katolikkerne. Den er sammensat af en række elementer, hvoraf nogle genfindes i arbejderklassen i andre lande, medens andre er specifikt knyttet til den nordirske samfundsstruktur. Som udgangspunkt kan bruges Sennett og Cobb's dybtgående analyse af holdninger til race- og lignende spørgsmål i den amerikanske arbejderklasse og deres fremhævelse af det dybtliggende behov for respekt og anerkendelse hos arbejderen, og af selvopofrelsen som det yderste bevis på menneskeværd, når alt andet svigter. ${ }^{19}$

Et rutinemæssigt og opslidende arbejde udført for folk, der behandler en »som om man var skidt«, »som om man var en del af kulisserne«, har for arbejderen ikke nogen mening i sig selv. Det tilskrives en ydre mening af nødvendigheden af at forsørge familien. Men katolikken, der ofte identificeres med den der lever af socialunderstøttelser, udgør en trussel mod den værdighed der hidrører fra rollen som forsørger. Ofte føler protestanterne, at han slet ikke er villig til at arbejde, at han foretrækker at leve af socialhjælp, og at han får sine mange børn, ja at hans kirke ligefrem opfordrer ham dertil, fordi han med arbejdsløshedsunderstøttelse og børnebidrag kan klare sig bedre, end hvis han bestiller noget. Ved

18. Om Unionisternes forsøg på at splitte arbejderbevægelsen, se, blandt utallige andre, Andrew Boyd, op. cit.

19. Richard Sennett and Jonathan Cobb: The Hidden Injuries of Class, Knopf, New York, 1972. Se også af samme: »Betrayed American Workers«, New York Review of Books, 5. okt. 1972, s. 31 ff. 
samtaler med protestantiske arbejdere får man et stærkt indtryk af den fascination katolikkernes børneflokke udøver på dem. De kender gerne flere eksempler på katolske familier med op mod et dusin børn, og de mener at vide, at med tolv børn behøver man ikke at arbejde. Enhver katolik, der har så mange børn, er stedse under mistanke for at være arbejdsløs af egen fri vilje, eller, hvis han har arbejde, for at overveje at lægge op og leve på andres bekostning. Selv om den protestantiske arbejder godt ved, hvad det vil sige at være arbejdsløs - han har sikkert prøvet det selv - så overvurderer han gerne i sine mere lidenskabelige øjeblikke understøttelsens omfang og overser den nedværdigelse, der følger med.

Blot et enkelt, måske indbildt eksempel på folk, der lever af socialhjælp, fordi de ikke gider arbejde, rejser tvivl om nødvendigheden af hans eget offer og gør ham overflødig som forsørger. Det er måske ikke så meget katolikker som sådan, han misbilliger, som det er folk, der har givet op i kampen for at vinde andres respekt, folk, der har opgivet al værdighed, og som alligevel, trods dette, finder sympati hos myndighederne og understøttes af staten, samtidig med at samfundet nægter at se, at hans, den protestantiske arbejders, ofre giver ham en ret til andres respekt. For den protestantiske arbejder har samfundet kun ringeagt og skældsord, selv om han, bomberne og terroren til trods, yder sin daglige indsats, medens katolikken, der måske slet ikke yder noget, bliver fremstillet som martyr.

Er hans egne ofre meningsløse, fordi familien kunne klare sig uden dem, så kan han kun begrunde dem ved en moralsk selvhævdelse: »jeg arbejder for pengene.« Selvopofrelsens moralske aspekt bliver den sidste udvej til at bevise sit værd, og offerhandlingen som sådan må derfor tilskrives en så altoverskyggende moralsk betydning, at den alene kan holde individet oppe. I sin søgen efter respekt trækker den protestantiske arbejder sig derfor ind i en gammeldags puritanisme og en arbejdsmoral, der i Nordirland yderligere understøttes af den herskende protestantiske etik med dens nære forbindelse til Calvinistisk nøjsomhed og strenghed. Katolikkerne, med deres mindre ansvarstyngede etik og mindre strenge levevaner, er derfor ikke blot moralsk forkastelige, men deres blotte tilstedeværelse rammer protestanten langt dybere, fordi de ved deres mere afslappede forhold til arbejdets moralske værdi drager den moral i tvivl, som han selv må klynge sig til. Den katolske etik, sådan som protestanten forestiller sig den, indeholder implicit en vragen af hans eget krav på værdighed.

Protestantens forkastelse af de levevaner, han i mere ophidsede stunder tilskriver katolikkerne, og hans fordømmelse af den tro, de formodes at udspringe af, giver sig udseende af at være en strid om moralske og teologiske forhold: en konflikt om religion. Men bag denne forkastelse og bag denne fordømmelse ligger dybest set protestantens fortvivlede kamp for anerkendelse og værdighed.

Den katolske nabo eller kollega er nok katolik, og som sådan udenforstående, men han er først og fremmest en nabo eller en kollega, med hvem man har et 
bredt spektrum af interesser tilfælles. Er forholdet mellem de to grupper forsigtigt, så er det dog også ofte egentligt tillidsfuldt. Men netop fordi afstanden til katolikken er så kort, det daglige samvær så forholdsvis nært og interessesammenfaldet så vidtgående bliver den følelsesmæssige udløsning så meget mere intens, når man pludselig ikke mere tør stole på sin nabo og - med rette eller med urette - tror at måtte forsvare familie og hjem med våben i hånd. Frygten, vreden og følelsen af at være blevet forrådt når over for katolikken en intensitet, som angreb fra andre klasser i samfundet slet ikke ville kunne give anledning til.

Den protestantiske arbejder ved nok, at tolerance over for katolikkerne er den »rigtige«, den »oplyste« holdning, men når han møder den blandt sine egne eller konfronteres med den udefra, så er det ikke den kristne næstekærlighed, han læser i den, men den fordømmelse af ham selv, der uvægerligt gemmer sig bag dyden. Han ved, at hans fjendtlighed over for katolske arbejdsfæller og naboer, folk i hans egne kår og med hans egne problemer, er virkelig, og at den er uværdig. Han ved, hvor fristende det er at søge anerkendelse hos dem, der står over ham socialt, ved at indtage en »oplyst « holdning, men netop derfor ved han også, at når en af hans egne præker tolerance og næstekærlighed, så er det ikke så meget fordi han ser anderledes på katolikkerne eller opfører sig anderledes over for dem, som det er et middel til at indynde sig andre steder ved at hæve sig over sine klassefæller: ved at fordømme dem. Kravet om større tolerance føles altid af den protestantiske arbejder som en anklage mod ham selv.

Vreden bliver ikke mindre, hvis det er fra de socialt højerestående, anklagen kommer. Her er folk, der fæller moralske domme over andre uden selv at have oplevet helvedet. De tror, at fordi de har en bedre uddannelse, kan de forstå ting bare ved at læne sig tilbage og tænke. De har ikke bragt noget offer for at forstå, de kender ikke frygten, truslerne, bomberne, razziaen. Og vel er dommen berettiget, men den er også uretfærdig, for de liberale freds- og fordragelighedsprædikanter i overklassen har kun øje for den ene side af sagen. De overser hvordan det daglige slid passes fredsommeligt sammen med katolske kammerater. Overklassens letkøbte humanisme og "forståelse « for katolikkerne (som de overhovedet ikke kender) er det, arbejderen mindst af alt kan finde sig i, for selvfølgelig er han ikke dummere end at han kan se hvordan den blot dækker over en foragt for ham selv og et forræderi over for ham, der er ved at blive fuldbyrdet.

Den protestantiske arbejder ved også godt, at hans modsætningsforhold til den katolske arbejder umuliggør en fælles front og kun gavner de, der undertrykker dem begge. Og heri finder han måske sit vanskeligste dilemma, affødt som alle de andre af den saks, han er fanget i, mellem den protestantiske middelog overklasse på den ene side og den katolske arbejderklasse på den anden. For at undgå at Nordirland indlemmes i Republikken, er de protestantiske arbejdere tvunget til at give deres politiske støtte til folk, som de ikke har tillid til, 
og som ikke på noget andet punkt taler deres sag. Mange ville have foretrukket en regering, der lå meget længere til venstre, et arbejderparti, man kunne støtte. Men med Labours traditionelle orientering mod de katolske nationalister har der ikke været nogen alternativer til det konservative og gennemgående arbejder- og fagforeningsfjendske Unionistparti.

Ledelsen af Unionistpartiet og den Protestantiske overklasse i almindelighed er altid under mistanke for forræderi. Skulle det komme til en genforening med Republikken under katolsk dominans, skal de nok vide at få deres på det tørre, men hvad med den lille forretningsindehaver, landarbejderen, arbejdsmanden? Som tingene er nu, kan de dog finde en smule tryghed i det forhold, at de store i samfundet har brug for dem, i hvert fald som stemmekvæg. Men i en katolsk republik vil det fornuftsægteskab være slut, og solidaritet fra overklassen skal de ikke regne med. Enhver tale om indrømmelser til katolikkerne og om at der engang må findes en løsning på forholdet til Republikken, bliver for de protestanter, der ikke har råd til at være liberale, et forvarsel om et kommende forræderi, hvor de selv skal lades i stikken. Alle tegn på afvigelse fra den protestantiske politiske ortodoksi vækker derfor forbitrelse, modstand og mistro hos de protestantiske arbejdere, ikke fordi man ikke under katolikkerne bedre kår, men fordi de implicit udgør en anklage mod en selv, et forvarsel om, at man vil blive svigtet, og en påmindelse om, at man er forsvarsløs. Som det sikkert også gælder mange andre steder, er intolerancen, »racismen « og bagstræbet hos den protestantiske arbejder i Nordirland først og fremmest resultatet af følelser af mindreværd og selvanklage, af moralsk isolation, af sårbarhed og af frygt.

Forholdet til England er ambivalent på samme måde som forholdet til den protestantiske overklasse. Et er loyaliteten over for Dronningen og Flaget, der blot er symboler, man kan lægge i, hvad man vil. Et andet er loyaliteten over for England, sådan som det faktisk er. Den er som loyaliteten over for overklassen og Unionistpartiet: nødtvungen og modstræbende. Færdes man blandt protestantiske arbejdere i Nordirland, opdager man hurtigt, at deres følelser over for England nok er forskellige fra katolikkernes, men ikke meget varmere. Blandt protestanterne i de lavere klasser føler man, at man fra alle sider bliver gjort til syndebuk for forhold og overgreb, som dog er englændernes værk. Det var englænderne, der under Cromwell massakrerede den irske befolkning og konfiskerede dens jord, englænderne, der i rationalismens og liberalismens hellige navn lod stå til under den store hungerkatastrofe, englænderne, der brutalt slog oprøret ned og henrettede lederne på stribe i 1916. Og intet i irsk historie vækker så hårrejsende minder som »Black and Tans«, et hastigt sammensat engelsk "politikorps«, der under borgerkrigen i 1920-21 hærgede Irland med terror og massakrer. Endnu idag skal de jævne protestanter gøres til syndebuk for den engelske hærs fremfærd mod katolikkerne i Belfast og Londonderry. 
Antipatien mod englænderne næres også af antipatien mod ens egen overklasse. Den er opdraget i England, taler med engelsk accent og har englændernes vaner, og, hvad der først og fremmest vækker mistro: den har forbindelser i England og har englændernes mere uengagerede holdning til religionen. Englænderne er næsten hedninge, og den protestantiske overklasse er mistænkt for det samme. Forventningen om et forræderi fra overklassens side gælder i endnu højere grad England. Også her er der for den jævne protestant tale om et fornuftsægteskab, der kun varer så længe England trods alt er det sikreste værn mod at blive opslugt i Republikken.

Den protestantiske arbejderklasses militante forsvar for orangevældet og dens modstand mod enhver indrømmelse over for katolikkerne kan altså ikke uden videre ligestilles med en slags anti-katolsk racisme. Modstanden mod indlemmelse i Republikken er nok primær, men det er modsætningsforholdet til den katolske nabo eller den katolske kollega derimod ikke. Det modsætningsforhold er snarere en underlig forvreden følge af, at modsætningsforholdet til den protestantiske overklasse ikke kan komme til udtryk på anden måde. For den protestantiske arbejder i Belfast er i en ganske anden situation end hans klassefæller i andre lande: Ved siden af ham - eller under ham - står en anden gruppe arbejdere, med hvem det på grund af nationalitetsspørgsmålet er umuligt for ham at identificere sig. Og denne gruppe har taget patent på alle de idealer, hvormed undertrykte i andre lande kan give udtryk for deres oprør mod magthaverne, deres trods mod samfundet og deres egen menneskeværdighed. De socialistiske revolutionære paroler, nationalbefrielsens retorik og stoltheden, værdigheden, håbet og trodsen i de undertryktes virkelige eller symbolske kamp mod undertrykkerne; alt dette har katolikkerne monopoliseret. Dybest set er den protestantiske arbejders kompromisløse orange loyalisme en erstatning for det oprør, der nægtes ham. Loyalismen står tilbage som det eneste terræn, på hvilket han kan hæve sig moralsk over de, der socialt står over ham, og erhverve en ret til at trodse dem, til at anklage dem og til at dømme dem.

De protestantiske massers ultra-orange loyalisme er således et kompliceret resultat af de modsætninger, deres situation i et tvedelt klassesamfund indebærer. De er foragtet af den protestantiske elite, men må klamre sig til den, svigtet af den, men må forlade sig på den. Selv er de tvunget til at svigte deres katolske klassefæller og til at indtage en sekterisk holdning, som på en gang føles uværdig og reaktionær, men som samtidig er det eneste middel til selvhævdelse. I den tilspidsede situation, der har foreligget i de seneste år, hvor overklassens og Englands forræderi, deres undergraven af den orange samfundsorden og deres kapitulationspolitik over for katolikkerne er blevet en kendsgerning, glider denne ultra-orangeisme let over i det, der objektivt ingen sammenhæng har med den, men som subjektivt synes at være dens naturlige fortsættelse: hadet til 
katolikkerne, pogromerne og straffetogterne. Den glidning viser sig først, hvor modsætningerne er stærkest: i de sektorer af underklassen, hvor den moralske isolation, frygten og magtesløsheden er størst, blandt de arbejdsløse og de deklasserede. Ghettoerne og slumkvartererne er de første, der eksploderer.

Endnu engang ser man således, hvordan krigen mellem Falls Road og Shankill Road, så langt fra at være konfliktens kerne, blot er et fjernt og forvirret udtryk for tilspidsningen af den virkelige hovedmodsætning: modsætningen mellem orangevældet og den nye orden.

\section{Nationalisme, socialisme og imperialisme}

Fra enhver anden synsvinkel end lige netop statsborgerskab udgør protestanterne og katolikkerne i Nordirland to helt forskellige nationale grupper. De betegnes almindeligvis som protestanter og katolikker, men forskellen mellem dem er ikke alene, ikke engang primært religiøs. Det drejer sig i virkeligheden om to forskellige kulturer, der ikke har ret meget andet fælles end sproget. Ganske vist finder man både blandt protestanter og blandt katolikker en følelse af »irskhed «, men ligheden rækker ikke videre end til etiketten. Bag denne betegnelse findes nationale myter, forestillinger om irsk historie og om Irlands sjæl, og samfundsopfattelser og politiske ideologier, der er vidt forskellige. Det er knapt en overdrivelse at sige, at til trods for at de er sammensmeltet i en stat $i$ Nordirland, har de to gruppers dominerende ideologier intet til fælles. ${ }^{20}$

Den protestantiske arbejderklasses ideologi er allerede blevet berørt, og som nævnt er en ny form, domineret af teknokratiske og juridisk-politiske forestillinger ved at vinde terræn, både i den protestantiske og i den katolske middelklasse. Det der skal omhandles på dette sted, er den katolske arbejderklasses ideologi med dens centrale begreber om national undertrykkelse og national frigørelse og dens sammenhæng med socialistiske ideologier.

Som nationalistiske ideologier er det andre steder, er den irsk-katolske nationalisme et forholdsvis nyt fænomen, der har sin oprindelse i midten af det nittende århundrede og i den gælliske vækkelsesperiode. Også i lighed med andre nationalismer har den søgt at etablere en kontinuitet til fortiden, eller rettere: til en mytisk fortid, den selv har skabt. Den irsk-katolske nationalisme er derfor præget af romantiske genfortællinger af irernes kamp mod det engelske åg og det protestantiske herredømme og om et før-kolonialt, klasseløst samfund - alle

\footnotetext{
20. For en udenforstående iagttager er det oplagt, at der i Irland er to nationer: en katolsk og en protestantisk. Alligevel benægtes det lidenskabeligt af størsteparten af den katolske venstrefløj. Erkendelsen af at der findes to nationer i Irland, der på ingen måde falder sammen med de to stater, anses for at virke splittende på arbejderklassen. »To-nation-teorien«, som denne kendsgerning kaldes, når den skal benægtes og latterliggøres, blev genoplivet i slutningen af tresserne af ICO (Irish Communist Organisation - bestemt ikke at forveksle med det kommunistiske parti). Også på andre punkter er analyserne i ICO's teoretiske organ The Irish Communist blandt de skarpsindigste, der kan findes.
} 
sammen myter, hvis historiske grundlag er ligeså spinkelt, som grundlaget er for de tilsvarende protestantiske myter.

Det britiske herredømme betragtes som alle irske onders rod. I den socialistiske ideologi bliver det britiske herredømme til britisk imperialisme. På denne måde falder alt smukt på plads i et system, der synes at udgøre en sammenhængende og overbevisende socialistisk teori. Forudsætningen for socialisme i Irland bliver, at båndene til den britiske undertrykker skæres over. Det Orange fåmandsvælde i Nordirland (såvel som det "grønne« oligarki i Republikken) bliver den britiske imperialimes neo-kolonialistiske håndlangere og de Unionistiske arbejdere, lokket af usle privilegier, dens uforvarende redskaber. Vigtigst af alt: eksistensen af den fælles fjende, den britiske imperialisme, smelter katolikker og protestanter sammen til et »folk «, i hvert fald for så vidt angår deres objektive interesser. De nationale forskelle træder nok så bekvemt $\mathrm{i}$ baggrunden. Splittelser inden for folket skyldes »en falsk bevidsthed «, der selv er resultatet af imperialismens og dens lokale håndlangeres del-og-hersk politik.

Naturligvis må en hvilken som helst socialistisk teori fastslå, at i sidste ende har katolske og protestantiske arbejdere fælles interesser. Men det at inddrage den britiske imperialisme som den altoverskyggende faktor i Irlands historie har den særlige fordel, at det da bliver tydeligt, at det er de protestantiske, ikke de katolske masser, hvis bevidsthed er »falsk «: før eller siden vil de slutte sig til katolikkernes kamp, og det må ske i alt væsentligt på katolikkernes vilkår.

Så forskellige grupper som det kommunistiske parti, den hemmelige republikanske hær (IRA) og den radikale studentergruppe "People's Democracy« bygger alle deres ideologi og strategi på teorier af denne art. Det er den traditionelle republikanske opfattelse, næsten det eneste den »officielle« og den "provisoriske« fløj af IRA endnu har til fælles. I mellemkrigsårene var teorien nærmest at betragte som den Irske Republiks officielle ideologi (bortset naturligvis fra karakteriseringen af det grønne oligarki i syd som håndlanger for imperialismen på lige fod med det orange oligarki i nord), og det er næppe nogen overdrivelse at sige, at denne teori er hele den irsk-katolske nations herskende ideologi. Det er heller ikke overraskende, at den skulle have fundet så stor udbredelse på hele den katolske venstrefløj og langt ind i nationalistiske kredse. Den er netop tillokkende, fordi den forener nationalistiske og socialistiske ideologier. Ved hjælp af denne teori bliver kampen for socialisme og for »befrielsen« af »det besatte Irland « (dvs. Nordirland) to sider af samme sag, og de kommer til at optræde som den naturlige fortsættelse og de retmæssige arvtagere til hele den romantiserede fortid af kamp mod britisk herredømme og protestantisk undertrykkelse. Ved et enkelt kunstgreb, der består i at tolke begivenhederne med een fjende, britisk imperialisme, der på een gang er ikke-irsk og anti-socialistisk og som let lader sig identificere med protestantisk herredømme i Nordirland, 
kan man ophæve alle ideologiske selvmodsigelser, løse alle strategiske dilemmaer og støbe forskellige, hver for sig dybt rodfæstede traditioner sammen til een sammenhængende politisk ideologi.

I betragtning af, at den irsk-katolske nationalisme i forvejen i sine centrale begreber om national undertrykkelse og anti-imperialistisk kamp havde en vis socialistisk klang, var det uundgåeligt, at venstrefløjen skulle overtage denne ideologi rub og stub, iberegnet hele den nationalistiske bagage, og gøre genforeningen af Irland til et af sine programpunkter. Få blandt Europas nationalistiske ideologier kunne have frembragt en mere frugtbar grobund for socialistiske tanker end netop den irske, for irsk historie, sådan som den irske katolik læser den, er ikke historien om konger og krige, men om et udplyndret og forarmet folk og dets oprør mod undertrykkerne. I den irske mytologi har national kamp og klassekamp altid været uadskillelige. Der var i virkeligheden slet ikke tale om, at det katolske venstre »overtog « den nationalistiske ideologi: det katolske venstre var født af den ideologi og opvokset i den; dets egen ideologi forblev en variant af den irsk-katolske nationalisme, med visse forskelle i prioriteringen af de politiske mål, men med stort set de samme hovedbegreber og hovedantagelser og med en tydelig rangorden mellem komponenterne: det var en socialistisk ideologi, der var klippet til, så den passede i en nationalistisk ramme, ikke er nationalistisk ideologi, der fandt sin berettigelse i et socialistisk begrebssystem. Denne sammensmeltning af nationalistiske og socialistiske ideologiske komponenter og socialismens underordning under nationalismen er intetsteds tydeligere end i den store arbejderleder James Connolly's skrifter fra begyndelsen af århundredet. Han er stadig til den grad forbillede - for ikke at sige profet - for det irske venstre, at alle grupper og fraktioner hævder at være hans arvtager, og at hans værker synes hævet over diskussion. Det ideal om en irsk socialistisk republik, en bøndernes og arbejdernes republik omfattende alle øens 32 grevskaber, som han kæmpede for, er siden blevet et ufravigeligt dogme for hele venstrefløjen, hvis gyldighed idag (og på Connolly's tid) er aksiomatisk.

Hvor ideologisk tillokkende og historisk velunderbygget det end kan forekomme at være, at sammensmelte nationalistiske og socialistiske begreber til en teori om britisk imperialisme som hovedkraften i Irlands historie og søge at forklare hovedtrækkene ved det orange herredømme i Nordirland på denne måde, må det konstateres, at teorien ikke kan holde til en nøjere kritik. I virkeligheden er teoriens »bindemiddel«, den kraft, der styrer alt, forbinder alt og forklarer alt: den britiske imperialisme, simpelthen ikke nogen betydningsfuld faktor i nutidig irsk politik. Dertil kommer, at i det begrænsede omfang, den er en vigtig faktor, har den ikke sammenfaldende, men tværtimod modstridende interesser i forhold til orangevældet. 
Britiske interesser i Nordirland, fortidige og nutidige, kan opdeles i en række typer, der i og for sig alle burde gennemgås i detaljer. Her må vi dog nøjes med nogle få antydninger. En første vigtig kategori er Irlands geografisk bestemte strategiske betydning: øens mulige anvendelse som bagdør til England i krigene med Spanien, Frankrig og Tyskland. En anden hovedkategori er den udbytning af feudal art, der fulgte med koloniseringen: jordens ekspropriation til fordel for engelske godsejere. Begge disse imperialistiske interesser (i vid forstand) har tidligere spillet en stor rolle, og de synes hver for sig at være tilstrækkelige forklaringer for den oprindelige erobring og kolonisering af Irland, men idag har de naturligvis tabt enhver betydning. I begyndelsen af det nittende århundrede var der to andre faktorer, der spillede en vis rolle. Den ene var, at den direkte administrative og lovgivende magt over Irland gjorde det muligt for britiske fabrikanter at hindre fremvæksten af konkurrerende irske industrier, særligt i tekstilbranchen. Den anden var en slags kvasi-kapitalistisk udbytning af britiske arbejdere ved hjælp af irsk landbrug: forarmelsen af Irland gjorde det muligt at købe irske landbrugsprodukter meget billigt omregnet til de industrivarer, de blev købt med, således at værdien, dvs. vedligeholdelsesomkostningerne af britisk arbejdskraft, kunne holdes på et minimum og udbytningsgraden på et maksimum. ${ }^{21}$ Også disse faktorer har idag mistet enhver betydning.

Det betyder ingenlunde, at britisk imperialisme ikke længere spiller nogen rolle i Nordirland eller i Irland som helhed. Det betyder derimod, at den britiske imperialismes interesser nu om stunder er af en sådan art, at de tilgodeses lige så godt i Republikken som i Nordirland. ${ }^{22}$ Disse interesser afhænger ikke på væsentlig måde af fortsat administrativ kontrol. Vedligeholdelsesomkostningerne for Nordirland er en betydelig belastning for den britiske statskasse, og det er vanskeligt at pege på nogen fordele for britisk kapital, der kunne tænkes at opveje den udgift. ${ }^{23}$ Ligeså lidt er fortsættelsen af det orange styre og den videre splittelse af arbejderklassen i den britiske imperialismes interesse. Tværtimod:

21. Jvf. Christian Palloix: »Impérialisme et mode de production capitaliste«, L'Homme et la Société, No. 12, 1969, s. 190 .

22. I nutidens imperialisme, anskuet som et verdensomspændende system, er der naturligvis en mangfoldighed af interesser, der indgår: politiske, økonomiske, ideologiske, strategiske osv. For så vidt angår økonomiske fordele er den væsentligste faktor næppe den hjembringelse af profit fra udenlandske investeringer, der så ofte må stå for skud, men snarere reproduktionen, gennem imperialismen, af visse underudviklingstræk i de afhængige lande, hvorved priserne på deres eksportvarer forbliver på et lavt niveau. En værdioverførsel fra land til land af et omfang, der betyder noget, kan i hvert fald kun ske gennem et i en eller anden forstand »ulige« bytteforhold, da alle andre overførsler ikke er særligt store (jvf. Arghiri Emmanuel: L'échange inégal, Paris: Maspéro, 1969). I det omfang imperialistisk udbytning først og fremmest må søges i bytteforholdet mellem de varer de forskellige lande producerer, er det i hvert fald oplagt, at Irland (såvel Nord som Syd), langtfra at være offer for det verdensomspændende imperialistiske system, befinder sig i dets indbringende ende.

23. En forholdsvis nylig kilde vurderer det samlede årlige tilskud til Nordirland til at være mellem $110 \mathrm{og}$ 140 millioner pund. Dette er skatteydernes penge. Den del af beløbet der kommer tilbage i form af subsidier til britisk kapital, der investeres i Nordirland, er højt regnet 10\%. (Se Bades and Scott: What Price Northern Ireland?, Young Fabian Pamphlet, nr. 22, nov. 1970). Britiske virksomheder får meget nær samme subsidier i Republikken, og i dette tilfælde uden udgifter for den britiske statskasse. 
orangevældet er uforeneligt med den moderne kapitalismes politiske, ideologiske og økonomiske tarv. For britisk kapital er Irland (både i syd og nord) idag en vigtig kilde til billig arbejdskraft, et beskyttet miljø for skrantende virksomheder og et ikke uvæsentligt eksportmarked. Ingen af disse fordele ville forringes ved irsk genforening og irsk uafhængighed.

Sandheden er, at britisk kontrol over Irland mistede næsten enhver betydning (med de militærstrategiske interesser som en væsentlig undtagelse) hen mod slutningen af det nittende århundrede, og at den i dag næsten udelukkende er et passiv. Dette er grunden til at Gladstone var villig til at give øen selvstyre til gengæld for så begrænset en gevinst for britisk kapital som et flygtigt liberaltnationalistisk regeringssamarbejde i London. Det er også af denne grund, at modstanden mod irsk selvstyre ikke blev ført af den britiske kapitalistklasse. men af protestanter i Ulster, af de britiske konservative, officerer og godsejere. Det var disse kræfter, der gennemtvang delingen. Det var Ulster, ikke England, der forlangte Unionens opretholdelse, og det var kun modstræbende, at Ulster accepterede at få et eget parlament i Belfast, sådan som Londonregeringen forlangte. Det er kun ved at erkende, at de britiske imperialistiske interesser i Nordirland er af helt underordnet betydning, at man kan forstå, hvordan det kunne gå til, at Londonparlamentet gennem et halvt århundrede, nemlig siden 1921, så godt som aldrig har gjort brug af sin ret til at omstøde Belfastparlamentets beslutninger. Selv den i ordets snævreste forstand økonomiske betydning af Irland har længe været helt underordnet for britisk kapital. Havde det ikke været tilfældet, havde »den britiske imperialisme« næppe fundet sig i den for en gang skyld vaskeagte anti-imperialistiske politik, som den Irske Republik førte i trediverne.

Fejlen ved teorien om at den britiske imperialisme endnu skulle spille en dominerende rolle i Irland i anden halvdel af det tyvende århundrede, består i, at der ikke klart skelnes mellem imperialisme og kolonialisme. De afgørende konsekvenser denne forveksling indebærer for en socialistisk politisk strategi omtales senere, men allerede på dette sted må det konstateres, at selv i allergroveste tilnærmelse må konfrontationen analyseres som en kampsituation ikke mellem to, men mellem mindst tre parter: »imperialismen «, de »indfødte« (katolikkerne) og »indvandrerne« (protestanterne). ${ }^{24}$ Imperialismen og kolonialismen er ofte gået hånd i hånd, og når det er sket, så kan de to førstnævnte parter behandles som een. Sa har man den hyppigt anvendte, men for det meste misvisende beskrivelse af situationen som et opgør mellem »imperialisme« og »national befrielse«. Men identiteten mellem invandrernes og imperialismens interesser kan på ingen måde tages for givet. Almindeligvis vil de, der slår sig ned i kolonierne, efterhånden udvikle interesser, der er forskellige fra kapitalistinteres-

24. Se Arghiri Emmanuel: »White-settler Colonialism and the Myth of Investment Imperialism«, paper til det Internationale Symposium om Imperialismeteori ved Institut for freds- og konfliktforskning, København, april 1971. 
serne i deres hjemland. Det viser sig derfor ofte, at indvandrerne forsøger at rive sig løs fra moderlandet, så snart de ikke længere behøver kolonimagtens støtte for at klare sig mod de indfødte. Under varierende former er det det der er sket i samtlige indvandrerkolonier, begyndende med USA og endende med Rhodesia. Irland har ikke været nogen undtagelse, som det kan ses af den protestantiske modstand mod Unionen af 1801, hvor Irlands delvise selvstyre blev ophævet, af de trusler visse af orangevældets forsvarere har fremsat om en ensidig uafhængighedserklæring efter Rhodesisk model, og af den protestantiske modstand mod Londonregeringens overtagelse af magten i Nordirland i foråret 1972.

Den imperialistiske magt har på sin side sædvanligvis været utilbøjelig til at tilstå uafhængighed til et regime der kontrolleres af indvandrerne, og langt mere villig til at give uafhængighed til et regime, der ledes af og repræsenterer de indførte. Det viser hele afkoloniseringens historie. Rimelige forklaringer er det heller ikke svært at finde: ledes landet af indfødte, vil det være lettere at fastholde det (eller der vil være større sandsynlighed for, at det af sig selv forbliver) inden for rammerne for en neo-koloni, f.eks. som producent af billige råstoffer.

Meget er anderledes i Nordirland, og sådanne brede historiske generaliseringer kan ikke uden videre overføres. Alligevel turde det være klart, at det bestemt ikke er usædvanligt, at hovedmodsætningen i bestemte epoker af et lands historie skal søges i forholdet mellem indvandrere og imperialismen, medens de indfødtes interesser, selv om det kun er midlertidigt, er sammenfaldende med imperialismens interesser. Sagt i almene vendinger: en sådan kamp afspejler modsætningen mellem to forskellige måder at udbytte landet og de indfødte på, dvs. modsætningen mellem to uforenelige former for samfundsformation. Hvad der er sagt oven for om modsætningen mellem den orange samfundsorden og den moderne forvalter-kapitalisme i Nordirland illustrerer dette.

Begreber som imperialisme og kolonialisme, der er meningsfyldte, når det drejer sig om underudviklede lande, har ikke nødvendigvis nogen mening når de anvendes på nutidens anglo-irske forhold, og i det foregående har jeg hævdet, at de imperialistiske interesser i Nordirland er yderst beskedne. Ikke desto mindre er det klart, at i det omfang sådanne interesser faktisk eksisterer, så er de at finde på den nye kapitalistiske ordens side. Imperialismen er forbundet med de anonymt ejede virksomheder og storkoncernernes datterselskaber, ikke med fortidens familieejede og lokaltstyrede virksomheder, med regeringen og administrationen i Belfast, ikke med småbyernes lokalstyre og pampervæsen, med Irland som een økonomisk enhed, ikke med nordirsk provinsialisme. Og omvendt er den kolonialistiske herskerklasse netop det orange oligarki. Deraf de analogier med Mississippi og Sydafrika, som tidligere blev nævnt. Det er klart, at vi enten må afvise al snak om imperialismen som en væsentlig ydre kraft i irske anliggender med den begrundelse, at dens indflydelse er minimal - 
og der kan siges meget til fordel for det standpunkt - eller også må vi erkende, at hovedmodsætningen i Nordirland er at finde mellem orangevældet og imperialismen. Hermed opnår vi overensstemmelse med kendsgerningerne: Regeringen i London har konsekvent (siden 1968, da den overhovedet begyndte at interessere sig for Nordirland) søgt at fremskynde reformerne. Betegnende nok reformer af en art, der direkte ville undergrave orangevældet fra grunden af (hjemsendelse af den private orange hær, B-specialtropperne, valgreform på kommunalt- og amtsniveau, overflytning af ansvaret for boligpolitikken fra de lokale råd til centralregeringen, erstatning af de hidtidige 73 lokale myndigheder med 17 regionalråd osv.). Samtidig er den yderst begrænsede karakter af skiftende britiske regeringers interesser i Nordirland tydeligt fremgået af deres langvarige tøven med at overtage regeringsmagten og af den fortrinsstilling genoprettelsen af lov og orden hele tiden har haft, selv om gadekampene kun kunne stilnes gennem betydelige indrømmelser til de militante protestanter.

Det bør måske endnu engang understreges, at pointen ikke er at benægte at Nordirland er en del af en imperialistisk struktur. Hvilken indkredsning af imperialismebegrebet man end går ud fra, kommer Nordirland givetvis med. Men når imperialismen fremdrages som den altoverskyggende faktor, sådan som nordirske socialister gør, så analyserer man ikke dens rolle, men udpeger blot dogmatisk en hovedmodsætning, navngiver en hovedfjende og fastlægger en strategi. Men denne fjendes væsen er selvmodsigende og dens enhed en myte. At udpege orangevældet og imperialismen som to sider af samme fjende, altså som een fjende, det er at tilsidesætte de strategier, der går ud på at skærpe modsætningen mellem dem.

\section{Strategiske overvejelser}

I den forudgående analyse har jeg lagt betydelig vægt på ideologiske faktorer. Det skyldes, at det forekommer mig, at den væsentligste hindring for fremskridt i socialistisk retning i Irland er den sørgelige forfatning, hvori irske arbejderes klassebevidsthed befinder sig, og det irske folks forvrængede forestillinger om dets egen situation. I virkeligheden er de fremherskende ideologier så utilstrækkelige i forhold til, hvad en revolution kræver, at man allerede af den grund næppe vover sig for langt ud ved at fastslå, at socialismen ikke står på den umiddelbare dagsorden i Irland, og at Connolly's socialistiske republik vil forblive et fantasivæsen i endnu en rum tid. Selv om det for mange i Irland synes mindre selvopgivende alligevel at fremture i agitationen for "socialisme nu « tror jeg ikke, en sådan propaganda bidrager det ringeste til en socialistisk bevidsthed, men derimod at den blot øger den ideologiske forvirring ved at føje nye myter til de gamle.

Det synes derfor rimeligt at fastslå, at under de nuværende omstændigheder må politisk handling først og fremmest tage sigte på det ideologiske niveau. Det 
betyder, at på dette tidspunkt består den korrekte revolutionære strategi ikke i at producere selve den socialistiske revolution, men i at producere dens ideologiske forudsætninger. Efter dette må den politiske praksis indstille sig, såvel i dens materielle som i dens ideologiske aspekter. De enkelte politiske handlinger må med andre ord bedømmes ud fra den grad til hvilken de bidrager til at producere de objektive betingelser under hvilke arbejderklassens ideologiske frigørelse bliver mulig, og ud fra den grad til hvilken de gennemføres på revolutionær vis, dvs. den grad til hvilken den ved deltagelse i kampen indvundne erfaring i sig selv producerer korrekt analyse og korrekt bevidsthed.

I stedet for at udkæmpe deres småslag i begivenhedernes udkant i et håbløst forsøg på at tæmme en katolsk-nationalistisk bølge og vende den til en kraft for socialismen ville irske socialister ifølge denne analyse gøre klogere $i$ at deltage direkte i det, der er hovedkampen. Det er her tingene sker, det er her fremtiden afgøres, og det er her deltagelse i kampen kan medvirke til ideologisk afklaring. Men forudsætningen herfor er, at det erkendes, at det at knuse den orange samfundsorden og sætte »forvalter-kapitalismens« såkaldte »velfærdsstat« i dens sted er et skridt, der er historisk nødvendigt og historisk progressivt. Det er progressivt selv fra et socialistisk synspunkt, og det er det til trods for, at den nye samfundsorden uundgåeligt vil blive af neo-kolonialistisk art. Det er progressivt i samme forstand, som den franske revolution og Europas erobring af verden var det: Det nedbryder en stillestående, stivnet samfundsform, medvirker til at frigøre de arbejdende masser fra deres middelalderlige ideologiske spændetrøje, letter omgrupperingen af arbejderne efter klassekriterier og fremmer politisk lighed og visse ganske vist snævert begrænsede, men ikke desto mindre virkelige former for demokratisk magt. Alle disse vindinger er af afgørende betydning i den videre socialistiske kamp.

At se kampen mellem orangevældet og den nye kapitalistiske orden som blot en strid mellem forskellige borgerlige fraktioner, et internt opgør blandt Unionister, som ikke angår venstrefløjen, er at forsømme de muligheder for at udvikle en revolutionær klassebevidsthed i Irland, som der ligger i den kamp. Nok er det rigtigt, at hvad socialister end vælger at gøre, og hvor stærke de politiske kræfter der står bag orangevældet end måtte være, så er de økonomiske vilkår sådan, at den orange samfundsordens dage under alle omstændigheder er talte. Men det er langtfra uvæsentligt, hvordan denne samfundsmæssige transformation finder sted. Lader venstrefløjen blot stå til, så vil udviklingen formodentlig tage form af økonomisk stagnation og forfald, som man allerede ser det nu, hvorefter Unionisternes appeller om hjælp fra regeringen i London og fra den britiske og internationale kapital vil synes at være den eneste konstruktive politik. Socialister vil da fremtræde som urostiftere, folkefjender, der blot besværliggør myndighedernes indsats for at skabe ny beskæftigelse for arbejderne, samtidig med at Imperial Chemical Industries, Courtaulds, Du Pont og de andre internationale koncerner, der nok skal komme, 
når statssubsidier og arbejdsløshed er blevet høje nok og lønniveauet lavt nok, vil få det let i rollen som folkets velgørere. Venstrefløjen vil have givet afkald på enhver lederrolle og vil have afgivet det politiske initiativ til den progressive sektor af borgerskabet. Hermed vil man have skabt de ideologiske, de økonomiske og de politiske betingelser for en tålmodig, lydig og reformistisk arbejderklasse.

Hvis venstrefløjen derimod griber ind direkte i den centrale kamp, så kan den udnytte situationen på to måder: til at skole arbejderklassen og ruste den ideologisk ved at give den en korrekt forståelse af dens egne virkelige vilkår og til at frembringe de materielle betingelser, hvorunder arbejderklassens solidaritet på tværs af religiøse skel, og med den en virkelig socialistisk kamp, ikke længere er en utopi.

Det betyder på ingen måde en tilbagevenden til tressernes borgerretsbevægelse med dens reformistiske krav, for venstrefløjens mål må være at overtage det ideologiske lederskab og vende kampen mod orangevældet til en revolutionær kamp. Det betyder en total omrokering i alliancemønstret. Det vil uvægerligt støde på modstand i store dele af den protestantiske arbejderklasse, og da det forudsætter anerkendelse af status quo for så vidt angår den nordirske statsdannelse, kan det heller ikke undgå at vække modstand i store dele af den katolske arbejderklasse. En væsentlig fordel ligger netop i det forhold, at hvis og når socialister gør fælles sag med den »britiske imperialisme« og det progressive protestantiske lederskab, så er der et antal myter, der må tages op til revision. Både blandt protestanter og blandt katolikker er det almindeligt antaget, at det protestantiske herredømme og unionen med England er to sider af samme sag; at »kolonialismens« og imperialismens, orangevældets, den britiske regerings og den britiske kapitals interesser er sammenfaldende. Som vist er det i virkeligheden her, hovedmodsætningen er at finde. For at fremme en korrekt forståelse og dermed en revolutionær bevidsthed i den irske arbejderklasse synes den bedste strategi at være at afdække og uddybe denne modsætning. For derved tvinges både protestantiske og katolske arbejdere til at revidere deres nedarvede forestillinger. Bringes modsætningerne frem i lyset, må de tage stilling for den ene og mod den anden, men de kan ikke fortsætte med at alliere sig med begge, som protestanterne tror de gør, eller med at vende sig mod begge, som katolikkerne gør. Hvilke allianceforskydninger der end måtte blive resultatet, vil de gøre fællesaktioner af arbejdere på begge sider af religionsskellet lettere. Det værste ved den nuværende kamp mod »britisk imperialisme« er netop, at den gør varig den falske ligestilling af union med unionistisk styre. der er kernen i de ideologier, der splitter arbejderklassen.

På den anden side er det indlysende, at alliancen med Den nye Ordens våbendragere kun kan have en rent taktisk karakter. Den er nødvendig og progressiv under de nuværende forhold, intet mere. Dens strengt midlertidige og taktiske 
karakter må gøres klart for arbejderne på begge sider, og det er en af hovedopgaverne, fordi hovedvægten som nævnt må lægges på den ideologiske afklaring.

Kampen må derfor fremstilles, ikke som en kamp for »borgerrettigheder«, men som en revolutionær kamp, hvis mål det er at knuse resterne af en samfundsorden, som har umuliggjort ethvert fremskridt mod socialismen og vil fortsætte med at gøre det, så længe den eksisterer. Man må fremstille borgerrettigheder og andre reformer, som står på den øjeblikkelige dagsorden, og kæmpe for dem, ikke i det perspektiv der er middelklassens: liberal reformisme, tilpasning og lapperi og »retfærdighed « for katolikker, men i den revolutionære socialismes ideologiske perspektiv: det er ikke et mål i sig selv, kampens indsats, men et middel, og, som allerede konstateret, et overordentligt virkningsfuldt middel til at angribe den orange samfundsorden i selve dens grundvold.

Skal venstrefløjen kunne deltage effektivt i kampen mod Orangevældet, så må den nødvendigvis tage afstand fra den katolsk-nationalistiske retorik og anerkende eksistensen af den nordirske statsdannelse. Så længe man ikke gør det, så støtter man i virkeligheden Orangevældet ved at forsyne det med et hårdt tiltrængt skræmmebillede, der kan bruges over for de protestantiske arbejdere. Det der er behov for, er et arbejderparti med tre punkter på programmet: (1) betingelsesløs accept af Irlands deling som ønskværdig og definitiv; (2) lighed og solidaritet mellem arbejdere uanset religion; (3) fremme af arbejderklassens økonomiske, sociale og politiske interesser. Det første punkt er næsten det vigtigste, for det er en forudsætning for at få den protestantiske arbejderklasse i tale, og dermed en forudsætning for begge de efterfølgende punkter. Som jeg har søgt at vise ovenfor, vil et parti, der står urokkeligt fast i grænsespørgsmålet og som samtidig kan udtrykke modsætningsforholdet til de herskende klasser, ikke blot kunne få de protestantiske arbejdere i tale, men det ville også ved at ophæve de modsætninger deres »anti-katolicisme« er resultatet af, kunne skabe grundlaget for en solidaritet i arbejderklassen. På tilsvarende vis har jeg antydet, at de katolske arbejderes krav om genforening med Republikken i virkeligheden er ambivalent og snarere udtrykker et behov for en oprørsretorik end et virkeligt politisk mål.

Spørgsmålet om hvilken holdning man bør indtage over for krav om national selvbestemmelse, volder ofte vanskeligheder for venstrefløjen, fordi der er en tilbøjelighed til at påberåbe sig generelle principper, hvorved man uundgåeligt ender i den rene moralisering. Opdeling af stater i mindre enheder med større etnisk homogenitet - hvadenten det drejer sig om Irlands adskillelse fra England eller om Ulsters adskillelse fra Irland - er naturligvis ikke noget fremskridt i sig selv. Ofte er det vel snarere et tilbageskridt, fordi stærke nationale bevægelser så let skjuler klassekampen bag en maske af nationalt sammenhold I virkeligheden kan man ikke opstille almengyldige regler. Krav om national uafhængighed må der altid tages stilling til på grundlag af en analyse af de kon- 
krete forhold, ${ }^{25}$ nemlig i lyset af den måde hvorpå de påvirker de pågældende folks socialistiske kamp.

Tesen om at de nordirske protestanter udgør en separat national enhed, der har ret til at nægte indlemmelse i Repuklikken, betragtes gerne som en tese. der kun tjener til at splitte arbejderklassen og derfor er anti-socialistisk og reaktionær. Jeg tror tværtimod det er de stædigt gentagne postulater om enhed og solidaritet, hvor ingen enhed og ingen solidaritet findes, og de irske katolikkers urimelige krav om at eje hele øen, der splitter. Det katolske venstre kræver en republik, der omfatter alle 32 grevskaber, og for at gøre pillen mindre bitter for protestanterne anfører man, at det skal være en socialistisk republik og dermed nødvendigvis en verdslig republik. Protestanterne ville være tåber, hvis de hoppede på den. Socialismen står ikke på dagsordenen i Irland, og selv om den gjorde det, forsvinder dybt rodfæstet sekterisme ikke fra dag til dag. Ved at støtte kravet om et forenet Irland har det katolske venstre blot formået at vise, at selv de, der påstår, at de udgør den socialistiske fortrop, sidder fast i den katolsk-nationalistiske ideologis hængedynd.

Til syvende og sidst stiller man tingene på hovedet, når man kræver en samlet irsk republik og håber, at den sidenhen vil kunne udvikle sig i socialistisk retning. Ville man fastlåse de religiøse skel fandtes ingen sikrere vej end at gennemtvinge en samling af Irland imod næsten en fjerdedel af befolkningens vilje; og en stat oprettet på denne måde ville højst blive socialistisk af navn. Irlands genforening vil komme efter sekterismen i Nordirland er blevet fejet af bordet, og efter man i syden har opgivet sine ekstravagante krav. Derefter kan der, for at sige det som Marx, efter adskillelsen komme en føderation, ${ }^{26}$ men vel at mærke en føderation, der bygger på ligeberettigelse mellem nationer og på international arbejdersolidaritet. At begynde med en påtvungen forening er at forråde internationalismens, socialismens og demokratiets idealer. Men det er også at forråde arbejderklassen og dens kamp for socialisme. For det at fastholde protestanternes ret til at holde sig uden for en irsk republik er ikke i første række et krav om »retfærdighed « for protestanter: det er først og fremmest forudsætningen for den katolske arbejderklasses ideologiske frigørelse. For som vi har set, fører det katolske venstres krav om Irlands genforening og dets forsøg på at forlige socialistiske og nationalistiske ideologier, til vildledende teorier og Don Quixotiske slag. Derved hindrer det arbejderne på begge sider af religionsskellet $\mathrm{i}$ at opnå en korrekt forståelse af den objektive situation, de befinder sig i. Virkelig enhed og virkelig socialisme opstår ikke af ideologisk forvirring og fejlrettede slag.

25. Jvf. hvordan Marx skiftede standpunkt i spørgsmålet om irsk uafhængighed (breve til Engels dateret 2. november 1867 og 10. december 1869). Hans støtte til irsk uafhængighed begrundedes med to forhold: Irlands behov for toldbeskyttelse overfor England og for landreform, og hans tro på at Irlands frigørelse fra England var blevet en forudsætning for, at den engelske arbejderklasse kunne frigøre sig selv. Jvf. også Lenin: The Right of Nations to Self-Determination, særligt sektion 8.

26. Marx til Engels, 2. november 1867. 